\title{
Induction of Anti-Hebbian LTP in CA1 Stratum Oriens Interneurons: Interactions between Group I Metabotropic Glutamate Receptors and M1 Muscarinic Receptors
}

\author{
[Caroline Le Duigou, ${ }^{1,2}$ EEtienne Savary, ${ }^{1}$ Dimitri M. Kullmann, ${ }^{2}$ and Richard Miles ${ }^{1}$ \\ ${ }^{1}$ Inserm U1127, CNRS UMR7225, Sorbonne Universités, UPMC UMR S1127, Institut du Cerveau et de la Moelle épinière, Paris 75013, France, and \\ 2Department of Clinical and Experimental Epilepsy, UCL Institute of Neurology, University College London, Queen Square, London WC1N 3BG, United \\ Kingdom
}

An anti-Hebbian form of LTP is observed at excitatory synapses made with some hippocampal interneurons. LTP induction is facilitated when postsynaptic interneurons are hyperpolarized, presumably because $\mathrm{Ca}^{2+}$ entry through $\mathrm{Ca}^{2+}$-permeable glutamate receptors is enhanced. The contribution of modulatory transmitters to anti-Hebbian LTP induction remains to be established. Activation of group I metabotropic receptors (mGluRs) is required for anti-Hebbian LTP induction in interneurons with cell bodies in the CA1 stratum oriens. This region receives a strong cholinergic innervation from the septum, and muscarinic acetylcholine receptors (mAChRs) share some signaling pathways and cooperate with mGluRs in the control of neuronal excitability.

We therefore examined possible interactions between group I mGluRs and mAChRs in anti-Hebbian LTP at synapses which excite oriens interneurons in rat brain slices. We found that blockade of either group I mGluRs or M1 mAChRs prevented the induction of anti-Hebbian LTP by pairing presynaptic activity with postsynaptic hyperpolarization. Blocking either receptor also suppressed longterm effects of activation of the other G-protein coupled receptor on interneuron membrane potential. However, no crossed blockade was detected for mGluR or mAchR effects on interneuron after-burst potentials or on the frequency of miniature EPSPs. Paired recordings between pyramidal neurons and oriens interneurons were obtained to determine whether LTP could be induced without concurrent stimulation of cholinergic axons. Exogenous activation of mAChRs led to LTP, with changes in EPSP amplitude distributions consistent with a presynaptic locus of expression. LTP, however, required noninvasive presynaptic and postsynaptic recordings.

Key words: hippocampus; interneuron; LTP; metabotropic glutamate receptors; muscarinic receptors

\section{Significance Statement}

In the hippocampus, a form of NMDA receptor-independent long-term potentiation (LTP) occurs at excitatory synapses made on some inhibitory neurons. This is preferentially induced when postsynaptic interneurons are hyperpolarized, depends on $\mathrm{Ca}^{2+}$ entry through $\mathrm{Ca}^{2+}$-permeable AMPA receptors, and has been labeled anti-Hebbian LTP. Here we show that this form of LTP also depends on activation of both group I mGluR and M1 mAChRs. We demonstrate that these G-protein coupled receptors (GPCRs) interact, because the blockade of one receptor suppresses long-term effects of activation of the other GPCR on both LTP and interneuron membrane potential. This LTP was also detected in paired recordings, although only when both presynaptic and postsynaptic recordings did not perturb the intracellular medium. Changes in EPSP amplitude distributions in dual recordings were consistent with a presynaptic locus of expression.

\section{Introduction}

Long-term synaptic potentiation (LTP) has multiple forms. One form, anticipated by Hebb (Hebb, 1949), is induced when a pre-
The authors declare no competing financial interests.

This article is freely available online through the J Neurosci Author Open Choice option.

Correspondence should be addressed to Dr Caroline Le Duigou, ICM, CHU Pitié-Salpêtrière, 47 bd de I'Hôpital, Paris 75013, France. E-mail: caroline.leduigou@gmail.com.

DOI:10.1523/JNEUROSCI.0956-15.2015

Copyright @ 2015 Le Duigou et al.

This is an Open Access article distributed under the terms of the Creative Commons Attribution License Creative Commons Attribution 4.0 International, which permits unrestricted use, distribution and reproduction in any medium provided that the original work is properly attributed. 
synaptic neuron fires synchronously with a postsynaptic cell. Induction of "Hebbian" LTP depends on NMDA receptors (NMDARs), which mediate postsynaptic $\mathrm{Ca}^{2+}$ entry at depolarized potentials. Expression involves increases in the number and/or changes in the properties of postsynaptic AMPA receptors (AMPARs; Benke et al., 1998; Malinow and Malenka, 2002; Bredt and Nicoll, 2003). Synapses which excite hippocampal (Bliss and Lomo, 1973; Morris et al., 1986) and neocortical (Jay et al., 1995; Heynen and Bear, 2001) principal cells express Hebbian LTP. Although Hebbian LTP is conventionally presented as a glutamate receptor narrative, it is modulated by other transmitters. Thus aminergic systems enhance LTP (Thomas et al., 1996; Lin et al., 2003) via second-messenger effects on glutamate receptor trafficking.

In contrast, NMDARs are not required for LTP at excitatory synapses on some interneurons. Instead, $\mathrm{Ca}^{2+}$-permeable AMPARs have been implicated in LTP at glutamatergic synapses made with hippocampal interneurons including those of the CA1 stratum oriens (Lamsa et al., 2007; Szabo et al., 2012) and basket cells (Le Roux et al., 2013). This NMDAR-independent LTP may be preferentially induced when the postsynaptic cell is maintained at hyperpolarized potentials when $\mathrm{Ca}^{2+}$ entry via $\mathrm{Ca}^{2+}$ permeable AMPARs should be enhanced, in contrast to the classical Hebbian induction paradigm. Although anti-Hebbian LTP may be induced postsynaptically, it appears to be expressed as an increased probability of glutamate release, similar to NMDAR-independent LTP induced with other protocols (Perez et al., 2001; Nicholson and Kullmann, 2014; but see Le Roux et al., 2013).

Some interneurons located in CA1 stratum oriens express metabotropic glutamatergic receptors (mGluRs) at high levels (Baude et al., 1993; Ferraguti et al., 2004). Group I mGluRs play an important role in LTP induction at synapses which excite these inhibitory cells (Lamsa et al., 2007; Le Duigou and Kullmann, 2011). This region is also strongly innervated by cholinergic fibers (Frotscher and Léránth, 1985). Muscarinic receptor $(\mathrm{mAChR})$ activation increases oriens interneuron excitability (Lawrence et al., 2006a,b; Widmer et al., 2006) but has not been shown to modulate synaptic plasticity. mAChRs and mGluRs interact synergistically in the control of CA1 pyramidal cell excitability (Graves et al., 2012; Park and Spruston, 2012) but possible interactions in LTP induction have not yet been explored.

We therefore asked how mGluR and $\mathrm{mAChR}$ signaling might interact in anti-Hebbian LTP. We found that activation of both neurotransmitter receptors was required to induce long-term plasticity at synapses that excite oriens interneurons. Further, antagonists to either receptor blocked effects of the other on the interneuron membrane potential. In contrast, the effects of mGluRs or mAchRs on interneuron after-burst potentials, a postsynaptic property, or on the frequency of miniature EPSPs, a presynaptic characteristic, were not affected by antagonists at the other receptor. We also performed paired recordings between presynaptic CA1 pyramidal cells and postsynaptic oriens interneurons to look for changes in trial-to-trial amplitude fluctuations of synaptic signals induced by $\mathrm{mAChR}$ activation. Changes in the amplitude distributions of unitary EPSPs were consistent with a presynaptic locus of expression for anti-Hebbian LTP.

\section{Materials and Methods}

Hippocampal slice preparation and maintenance. Animal experiments followed the Scientific Procedures Act (UK, 1986), the European Committee Council Directive (2010/63/UE), and INSERM (France) guidelines. Transverse $350 \mu \mathrm{m}$ hippocampal slices were prepared from male
Sprague-Dawley rats, of age P20-P30, after terminal pentobarbital anesthesia $(140 \mathrm{mg} / \mathrm{kg})$. Slices were cut with a vibrating microtome (VT1000S, Leica) in a solution bubbled with $5 \% \mathrm{CO}_{2}$ in $95 \% \mathrm{O}_{2}$, cooled to $0^{\circ}-2^{\circ} \mathrm{C}$, and containing the following (in $\mathrm{mm}$ ): 70 sucrose, $80 \mathrm{NaCl}, 2.5$ $\mathrm{KCl}, 1.25 \mathrm{NaH}_{2} \mathrm{PO}_{4}, 25 \mathrm{NaHCO}_{3}, 7 \mathrm{MgCl}_{2}, 0.5 \mathrm{CaCl}_{2}$, and 25 glucose, resulting in a $\mathrm{pH}$ of 7.3 and an osmolarity of $315 \mathrm{mOsm}$.

After preparation, slices were kept at $20^{\circ}-25^{\circ} \mathrm{C}$ in a solution containing the following (in mM): $119 \mathrm{NaCl}, 2.5 \mathrm{KCl}, 26 \mathrm{NaHCO}_{3}, 1 \mathrm{NaH}_{2} \mathrm{PO}_{4}, 3$ $\mathrm{MgCl}_{2}, 2 \mathrm{CaCl}_{2}, 15$ glucose, and equilibrated with $5 \% \mathrm{CO}_{2}$ in $95 \% \mathrm{O}_{2}, \mathrm{pH}$ 7.3, and $297 \mathrm{mOsm}$. For recordings they were transferred to a chamber mounted on an upright microscope (BX50WI, Olympus). They were perfused at $3 \mathrm{ml} \cdot \mathrm{min}^{-1}$ with the storage solution above modified with $\mathrm{CaCl}_{2}$ increased to $2.5 \mathrm{~mm}$, and $\mathrm{MgCl}_{2}$ reduced to $1.3 \mathrm{~mm}$. Chamber temperature was controlled at $30^{\circ}-32^{\circ} \mathrm{C}$. Neurotransmitter receptors antagonists were present in all experiments: picrotoxin $(100 \mu \mathrm{M})$ and CGP52432 $(1 \mu \mathrm{M})$ were used to block GABA receptors, and DL-2-amino5 -phosphonovalerate $(50 \mu \mathrm{M})$ was present to block NMDA receptors. A cut was made between CA3 and CA1 regions to prevent the spread of epileptiform activity from the CA3 region.

Electrophysiology and data analysis. Neurons were visualized for recording with infrared differential interference contrast microscopy. Recordings were made from CA1 pyramidal cells and from interneurons with a soma in stratum oriens and dendrites running parallel to the stratum pyramidale. Pipettes of resistance $4-5 \mathrm{M} \Omega$ filled with a solution containing the following (in $\mathrm{mM}$ ): $110 \mathrm{~K}$ gluconate, $17.5 \mathrm{KCl}, 10 \mathrm{HEPES}$, 0.2 EGTA, $8 \mathrm{NaCl}, 2 \mathrm{MgATP}, 0.3 \mathrm{Na}_{3} \mathrm{GTP}, 5 \mathrm{QX}-314 \mathrm{Br}$, pH 7.2, and 296 $\mathrm{mOsm}$, were used for whole-cell recordings in current clamp. Because LTP could not be reliably induced in whole-cell mode, perforated patch recordings were made from interneurons in LTP experiments. Signals were amplified with a Multiclamp 700B amplifier (Molecular Devices). Membrane potential was filtered at $5 \mathrm{kHz}$, digitized at $10 \mathrm{kHz}$, and recorded with programs written in Labview (National Instruments) or with pClamp (Molecular Devices). Recordings were discontinued if the series resistance or holding current changed by $>25 \%$.

Excitatory synaptic events were elicited in interneurons of CA1 stratum oriens by local extracellular stimulation of pyramidal cell axons in stratum oriens/alveus. Axons were stimulated via two bipolar stainless steel electrodes placed on either side of the interneuron at the oriens/ alveus border (distance 100-500 $\mu \mathrm{m}$ ). Single or paired stimuli, at interval $50 \mathrm{~ms}$, were delivered alternately from the two electrodes at interval $15 \mathrm{~s}$ (stimulus duration 50-100 $\mu$ s; Digitimer). Averages of 20 events were used to estimate the paired-pulse ratio (PPR) of EPSP slope. After recording EPSPs for a control period, the plasticity induction protocol consisted of stimulating one pathway at $100 \mathrm{~Hz}$ for $1 \mathrm{~s}$ twice at interval 20 s. Responses to stimulating the other pathway were used as control. Interneurons were clamped at -90 to $-100 \mathrm{mV}$, during induction, to favor the anti-Hebbian form of plasticity.

Perforated patch recordings were made in some experiments to avoid washout of intracellular elements involved in the induction or expression of synaptic plasticity (Horn and Marty, 1988; Kullmann and Lamsa, 2007). Gramicidin (100 mg.ml ${ }^{-1}$; Sigma-Aldrich) was prepared daily in dimethyl sulfoxide and added (1:1000) to a pipette solution containing the following (in $\mathrm{mM}$ ): $145 \mathrm{~K}$-gluconate, $8 \mathrm{NaCl}, 20 \mathrm{HEPES}, 0.2 \mathrm{EGTA}$, and 5 QX-314 Br, pH 7.2, and 295 mOsm. The pipette tip was filled with gramicidin-free solution. Recordings began when the series resistance fell $<150 \mathrm{M} \Omega$, and were discontinued if depolarizing pulses no longer evoked action potentials. Current was injected if necessary to maintain the membrane potential between -75 and $-65 \mathrm{mV}$.

In some experiments, we measured afterpotentials induced in stratum oriens interneurons by bursts of action potentials ( 5 spikes at interval 2 $\mathrm{ms}$ elicited at interval $1 \mathrm{~min}$ ). Current-clamp recordings were made in perforated patch mode with a pipette solution containing the following (in mM): $117.5 \mathrm{~K}$ gluconate, $17.5 \mathrm{KCl}, 10 \mathrm{HEPES}, 0.2 \mathrm{EGTA}, 8 \mathrm{NaCl}, 2$ MgATP, $0.3 \mathrm{Na}_{3}$ GTP, 5 QX-314Br, pH 7.2, and 296 mOsm. Neurons were maintained at $-60 \mathrm{mV}$. The peak amplitude of the postburst afterhyperpolarization (AHP) or afterdepolarization was measured with respect to this holding potential.

Excitatory synaptic events induced in interneurons by single presynaptic CA1 pyramidal cells were monitored in some experiments. Pyrami- 
dal cell action potentials were elicited in whole-cell or cell-attached recordings (Perkins, 2006). The pipette solution for cell-attached recordings included $125 \mathrm{~mm} \mathrm{NaCl}$. Postsynaptic interneurons were recorded in whole-cell or perforated patch mode. In some paired recordings where the presynaptic pyramidal cell was held in whole-cell mode, the mean amplitude of postsynaptic responses declined with time. Cell pairs in which responses were not stable after 10 min were not analyzed.

Unitary EPSPs were analyzed from histograms of the distribution of noise and amplitude of evoked events ( $n=150-650$ traces). An average of evoked events was made. Potential differences were measured for all events between a time point at the peak of the averaged event and a point before the presynaptic spike (time difference $2-5 \mathrm{~ms}$ ). A noise distribution was obtained by measuring backward over the same time interval from the time point before presynaptic firing to a previous time point. Mean $_{\mathrm{N}}, \mathrm{SD}_{\mathrm{N}}$, and amplitude $\mathrm{N}_{\mathrm{N}}$ were derived from a least-squares fit to a Gaussian distribution describing the noise. The distribution of evoked events was described with a least-squares fit of the sum of two Gaussians. One used values obtained from the noise distribution for mean $\mathrm{N}_{\mathrm{N}}$ and $\mathrm{SD}_{\mathrm{N}}$, the other found best values for mean $\mathrm{E}_{\mathrm{E}}, \mathrm{SD}_{\mathrm{E}}$, and amplitude $\mathrm{E}_{\mathrm{N}}$, as well as a ratio for the amplitudes of the two distributions $\mathrm{r}_{\mathrm{E} / \mathrm{N}}$. This analysis provided estimates for the amplitude of EPSPs and their variability, as well as the proportion of evoked EPSPs and failures before and after the induction of synaptic plasticity.

Pharmacology. Activation of Group 1 mGluRs was suppressed using the antagonists LY 367385 [(S)-(+)-a-amino-4-carboxy-2-methylbenzeneacetic acid; $100 \mu \mathrm{M}$ ] and MPEP [2-methyl-6-(phenylethynyl)pyridine hydrochloride; $25 \mu \mathrm{M}$. mGluR receptors were activated using DHPG [( S)-3,5-di-hydroxyphenylglycine; $5 \mu \mathrm{M}$. Signaling at $\mathrm{mAChRs}$ was suppressed with atropine $(10 \mu \mathrm{M})$, a broad spectrum antagonist, or telenzepine (75 nM), a specific M1 receptor antagonist. $\mathrm{mAChRs}$ were activated with the broad-spectrum agonist oxotremorine $(\mathrm{OxoM} ; 5 \mu \mathrm{M})$. Miniature EPSCs were recorded in the presence of tetrodotoxin (TTX; $1 \mu \mathrm{M}$ ). The AMPA receptor antagonist GYKI $53655(25 \mu \mathrm{M})$ was used to reversibly suppress glutamatergic EPSPs.

Immunofluorescence assays. Brain sections of thickness $40 \mu \mathrm{m}$ were obtained from rats perfused with $4 \%$ paraformaldehyde. Slices were exposed to three freeze-thaw cycles on dry ice and rinsed for $1 \mathrm{~h}$ in PBS. A quenching step using a $0.3 \% \mathrm{H}_{2} \mathrm{O}_{2}$ solution in PBS was followed by saturation with a blocking solution of $10 \%$ normal donkey serum and $1 \%$ Triton X-100 for $1 \mathrm{~h}$. Slices were exposed overnight to primary antibodies in PBS containing $1 \%$ normal donkey serum at $4^{\circ} \mathrm{C}$. After washing with PBS, they were incubated with secondary antibodies in PBS for $2 \mathrm{~h}$ at room temperature. Cell bodies were revealed with DAPI $(10 \mu \mathrm{g} / \mathrm{ml})$. The primary antibodies used in this study were as follows: anti-mGluR $1 \alpha$ (polyclonal guinea-pig, Frontier Institute mGluRla-GP-Af660 1:500); anti-M1 mAChRs (polyclonal rabbit, Frontier Institute, mAChR-M1Rb-Af340 1:500). Secondary antibodies used are conjugated with AlexaFluor 555 or 488 (dilution 1:500; Invitrogen). Slices were mounted on glass slides using ProLong Gold Antifade Reagent (Life Technologies) as mounting medium. Images were made with a confocal microscope (Leica SP2 AOBS, AOTF) with laser wavelengths 405, 488, and $543 \mathrm{~nm}$ and a $40 \times$ objective of NA 1.25. Images were acquired at a $2048 \times 2048$ resolution for a final voxel size of $183 \mathrm{~nm}$ in $X$ and $Y$, and $1.25 \mu \mathrm{m}$ in $Z$, or with a macroscope (Nikon AZ100, equipped with DAPI, FITC, and TRITC filters; a Nikon digital Sight DS-Ri1; and a $2 \times$ objective of NA 0.2 .) Images were acquired at $1280 \times 1024$ resolution with a $2.5 \mathrm{zoom}$ for a final pixel size of $2.24 \mu \mathrm{m}$ ).

\section{Results}

\section{Both mAChRs and group I mGluRs are necessary for LTP induction}

LTP at excitatory synapses made with CA1 stratum oriens interneurons can be induced by pairing postsynaptic hyperpolarization with high-frequency stimulation of fibers in stratum oriens (Lamsa et al., 2007; Oren et al., 2009). This induction protocol in principle could also release neurotransmitters from nonglutamatergic synapses, such as those made by cholinergic fibers which project in this layer (Dutar et al., 1995; Fukudome et al., 2004; Fig. 1). We used immunofluorescence to examine the degree of overlap of mGluRla and M1 mAChRs (Fig. 1A-G). Immunoreactivity for muscarinic 1 receptors (M1 mAChRs) in stratum oriens was diffuse, whereas mGluR1 $\alpha$ was expressed by neurons close to the alveus (Fig. 1A). M1 mAChRs were located in CA1 pyramidal cell bodies and in some stratum oriens interneurons (Fig. $1 B, C-G)$. mGluRla was expressed in proximal dendrites of CA1 pyramidal cells and in the cell bodies of some interneurons in stratum oriens (Fig. $1 A, C-G$ ). The colocalization of $\mathrm{M} 1 \mathrm{mAChR}$ and mGluR1 in interneurons of stratum oriens raises the possibility that they interact in the induction of LTP.

We therefore asked whether cholinergic receptor antagonists influence anti-Hebbian LTP induction. In perforated patch recordings from interneurons, the control induction procedure led to an increase in EPSP slope to $158 \pm 2 \%$ of baseline, measured at 20 min after pairing (Fig. $1 H ; n=8$ interneurons). LTP at these synapses was prevented (Fig. $1 I$ ) by the broad-spectrum mAChR antagonist atropine $(10 \mu \mathrm{M})$. EPSP slope at $20 \mathrm{~min}$ after stimulation was $110 \pm 17 \%$ (paired $t$ test, $p=0.99, n=9$ ), although a short-term potentiation of $137 \pm 16 \%$ was apparent at $10 \mathrm{~min}$. The more specific M1 muscarinic receptor antagonist, telenzepine (75 nM; Levey et al., 1995; Rouse et al., 1999; Yamasaki et al., 2010), also prevented LTP ( $n=7$, paired $t$ test, $p=0.72$; Fig. $1 J)$. Thus M1 mAChR activation is required for induction of LTP at these excitatory synapses.

Activation of group I mGluRs has been shown to play a similar role in the induction of anti-Hebbian LTP at these synapses (Le Duigou and Kullmann, 2011). We confirmed that either the mGluR5 antagonist MPEP $(25 \mu \mathrm{M})$, or the mGluR1 blocker LY $367385(100 \mu \mathrm{M})$ prevented a maintained enhancement of EPSP slope. EPSP slope at $20 \mathrm{~min}$ was $90 \pm 10 \%$ $(n=9 ; p=0.31)$ when high-frequency stimulation was coupled with postsynaptic hyperpolarization in the presence of $\operatorname{MPEP}(n=7, p=0.14$; Fig. $1 K)$ and $110 \pm 14 \%$ when the induction protocol was delivered in the presence of LY 367385 $(n=7$; data not shown).

\section{Cooperation of group I mGluRs, mAChRs, and calcium- permeable AMPARs during LTP induction}

These data suggest that induction of LTP at these synapses may require not only the activation of calcium-permeable AMPA receptors (Oren et al., 2009) but also of mGluRs and mAChRs. We tested this hypothesis by asking whether pharmacological activation of the G-protein coupled receptors (GPCRs) induced long-term changes.

Pairing hyperpolarization of an interneuron recorded in perforated-patch mode with application of the mAChR agonist OxoM ( $5 \mu \mathrm{M} ; 10 \mathrm{~min}$ ), and/or the group I mGluR agonist, DHPG $(5 \mu \mathrm{M} ; 10 \mathrm{~min})$, induced an increase in EPSP slope. After activation of mAChRs by OxoM, EPSP slope increased to $158 \pm 3 \%$ of control values $(n=7 ; p=0.0003$; Fig. $2 A)$. After activation of group I mGluRs by DHPG, EPSP slope increased to $151 \pm 14 \%$ $\left(n=10 ; p=7 \times 10^{-8}\right.$; Fig. $\left.2 B\right)$. EPSP potentiation induced by DHPG, but not by OxoM, was preceded by a transient synaptic depression (Palmer et al., 1997; Fitzjohn et al., 1999; Gibson et al., 2008). However, no delayed potentiation was induced either when the agonist was applied (OxoM or DHPG) without membrane potential control nor when the interneuron was only hyperpolarized (data not shown; cf. Le Duigou and Kullmann, 2011). When both mGluR and mAChRs were simultaneously activated by coapplication of OxoM and DHPG, EPSPs were facilitated to a similar extent as by either agonist alone. EPSP slope at 40 min after induction was $156 \pm 20 \%(n=8 ; p=0.002$; Fig. $2 C)$. Coapplication of OxoM and DHPG also depressed EPSPs 

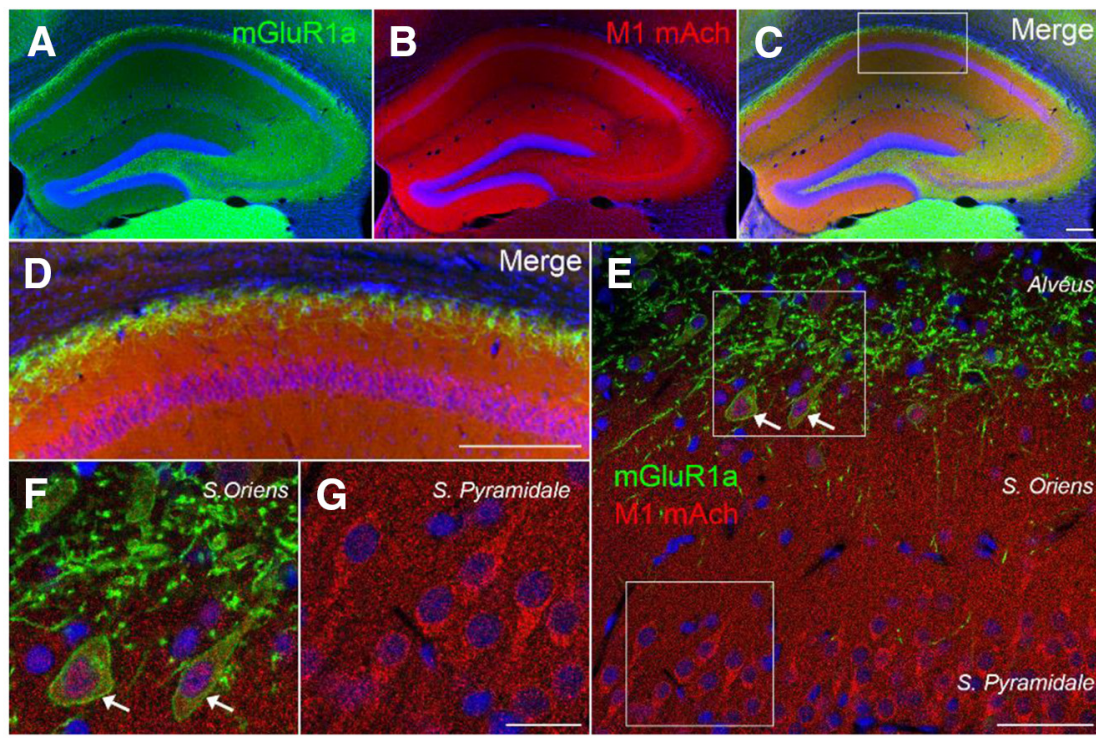

S. Pyramidale
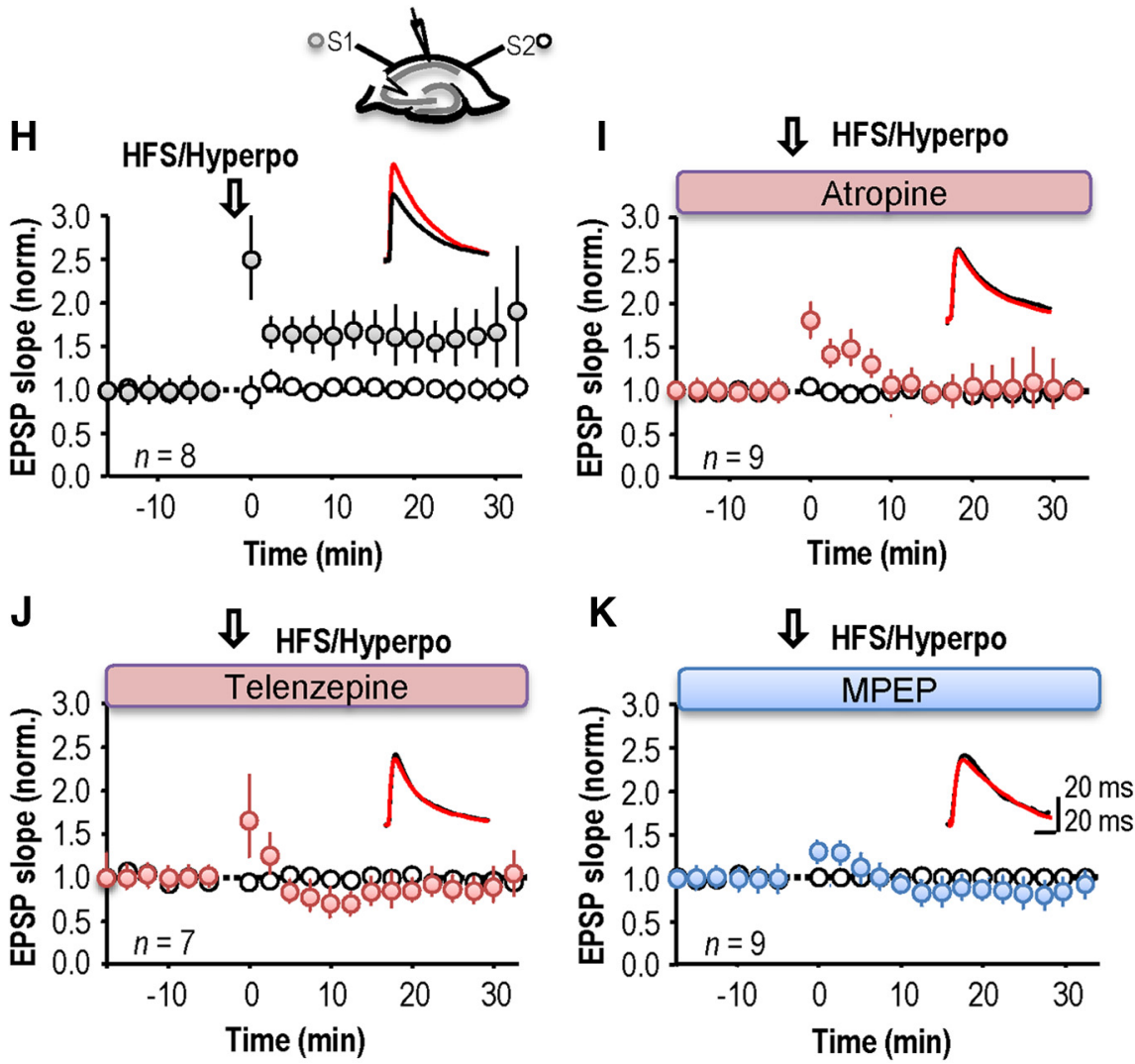

Figure 1. Blockade of $m A C h R s$ or group I mGluRs suppresses LTP induction in st oriens interneurons. $\boldsymbol{A}-\boldsymbol{G}$, Doubleimmunofluorescence of $\mathrm{mGluR} 1 \alpha$ and M1 mAChR in the hippocampus. Immunoreactivity for mGluR1 $\alpha$ is restricted to the alvéus of CA1 region, CA3 and hilus of dentate gyrus, whereas immunoreactivity for M1 mAChR is more distributed throughout the hippocampus $(\boldsymbol{A}-\boldsymbol{C})$. The $\mathrm{mGluR} 1 \alpha$ (green) is expressed in the proximal dendrite of CA1 pyramidal cells located in the alveus $(\boldsymbol{D}-\boldsymbol{F})$ and in some of the cell bodies of interneurons located in stratum oriens $(\boldsymbol{F})$. Even with a widespread expression, M1 mAChR (red) are more distributed in the cell bodies of CA1 pyramidal cells $(\boldsymbol{D}, \boldsymbol{E}, \boldsymbol{G})$, as well as in some stratum oriens interneurons $(\boldsymbol{F})$. Scale bars: $\boldsymbol{A}-\boldsymbol{D}, 200 \mu \mathrm{m} ; \boldsymbol{E}, 50 \mu \mathrm{m} ; \boldsymbol{F}, \boldsymbol{G}, 20 \mu \mathrm{m}$. $\boldsymbol{H}$, High-frequency stimulation (HFS; $2 \times 100 \mathrm{~Hz}, 1 \mathrm{~s}$ ) of oriens/alveus fibers (S1) coupled with postsynaptic hyperpolarization to $-90-110 \mathrm{mV}$ (Hyperpo) induced a long-term potentiation of EPSP slope in the stimulated (S1) pathway, but not the nonstimulated (S2) pathway. Top, Schema showing sites of stimulation, S1 and S2, and perforated patch recording. Inset, Representative sample traces from a single neuron before (black) and after (red) the LTP induction. I, Only a transient potentiation was induced in the presence of the broad spectrum mAChR antagonist atropine $(10 \mu \mathrm{M})$. $J$, The M1 mAChR antagonist telenzepine (75 nм) suppressed LTP. $\boldsymbol{K}$, LTP was suppressed by the type I mGluR antagonist MPEP (25 $\boldsymbol{\mu M}$ ). $\boldsymbol{H}-\boldsymbol{K}$, Each symbol represents an average of 20 events elicited at $15 \mathrm{~s}$ intervals and error bars show SEM. Time $t=0$ corresponds to the induction procedure. transiently, for a longer duration than the depression induced by DHPG alone.

We next asked whether ionotropic AMPA receptors must also be activated during the induction of plasticity by GPCRs. First, we investigated the requirement that the recorded interneuron be clamped to a hyperpolarized potential $(-80$ to $-100 \mathrm{mV})$. No potentiation was detected if interneurons were allowed to depolarize during application of OxoM or DHPG, (OxoM, $n=6$; DHPG, $n=7$; data not shown). Second, we asked whether OxoM or DHPG induced LTP when ionotropic glutamate receptors were blocked. For these experiments, EPSPs were completely and reversibly blocked $(n=9 ; p=$ 0.15 , paired $t$ test; Fig. $2 D$ ) using the AMPA receptor antagonist GYKI 53655 (25 $\mu \mathrm{M}$, bath application 5-7 min, recovery in $20-30 \mathrm{~min}$ ). Both group I mGluRs and $\mathrm{mAChRs}$ were activated by applying DHPG $(5 \mu \mathrm{M})$ and OxoM ( $5 \mu \mathrm{M} ; 10 \mathrm{~min})$ during EPSP suppression by GYKI 53655. This procedure did not induce LTP but rather led to a depression of EPSP slope to $76 \pm 2 \%$ at $40 \min (n=7, p=0.009$; Fig. $2 E)$. Such a synaptic depression may result from the activation of group I mGluR (Palmer et al., 1997; Fitzjohn et al., 1999; Mannaioni et al., 2001) or of $\mathrm{mACh}$ receptors (Auerbach and Segal, 1996; Shinoe et al., 2005; McCutchen et al., 2006; Dickinson et al., 2009). After transient suppression by GYKI 53655, EPSPs were not persistently enhanced at $60 \mathrm{~min}$, whether interneurons were hyperpolarized to -80 to $-100 \mathrm{mV}(n=4)$ or not $(n=3)$. Figure $2 F$ summarizes persistent changes in EPSP slope induced by applying mGluR and $\mathrm{mAChR}$ agonists in the absence or the presence of GYKI 53655 to suppress glutamatergic EPSPs during the induction procedure. We conclude that LTP induction at these synapses requires conjoint activation of $\mathrm{Ca}^{2+}$-permeable AMPARs, group I mGluRs and mAChRs.

\section{Crossed effects of M1 mAChRs and group I mGluR antagonists}

If LTP induction requires activation of both mGluRs and mAChRs, as well as calcium-permeable AMPA receptors, it should be suppressed by antagonists of either GPCR. To test this hypothesis, pharmacological activation of group I mGluRs or mAChRs was paired with interneuron hyperpolarization. Effects of this induction procedure were then tested in the presence of antagonists of the other GPCR (Fig. 3).

Application of the group I mGluR antagonists LY367386 (100 $\mu \mathrm{M})$ and 
MPEP $(25 \mu \mathrm{M})$ converted an OxoMinduced potentiation into a depression to $74 \pm 10 \%$ of control EPSP slope (Fig. $3 A 1$; at $30 \mathrm{~min}$; paired $t$ test, $p=3 \times$ $\left.10^{-7}, n=7\right)$. Similarly, application of the M1 mAChR antagonist telenzepine (75 nM) converted the DHPG-induced potentiation into a depression of EPSP slope to $72 \pm 9 \%$ (Fig. $3 \mathrm{B1}$; at $30 \mathrm{~min}$; paired $t$ test, $\left.p<10^{-7}, n=7\right)$. In both cases the depression tended to return toward baseline levels. These data reveal unexpected reciprocal actions of antagonists at M1 mAChRs and group I mGluRs during the induction of longterm plasticity.

\section{No evidence for presynaptic} interactions between M1 mACh and group I mGlu receptors

These data suggest that antagonists at M1 mAChRs suppress the actions of group I mGluRs in the induction of long-term plasticity and vice versa. We next asked whether a similar interaction was evident in the effects of these antagonists on a presynaptic property-glutamate release.

Miniature EPSCs (mEPSCs) were recorded in the whole-cell mode from stratum oriens interneurons in the presence of TTX $(1 \mu \mathrm{M})$. The muscarinic receptor agonist OxoM $(5 \mu \mathrm{M})$ increased the mEPSC frequency from $5.1 \pm 1.4 \mathrm{~Hz}$ to $7.8 \pm 2.5 \mathrm{~Hz}$; (Fig. $4 A, B ; n=9$; increase of $60 \pm 3 \%$; $p=$ 0.01 , paired $t$ test). Repeating the application of OxoM in the presence of the mGluR antagonists MPEP $(25 \mu \mathrm{M})$ and LY367386 $(100 \mu \mathrm{M})$ increased the mEPSC frequency from $3.4 \pm 0.8 \mathrm{~Hz}$ to $5.7 \pm 1.4 \mathrm{~Hz}$ (Fig. $4 A, B ; n=8$; increase of $110 \pm 50 \% ; p=$ 0.01 , paired $t$ test). Thus mGluR antagonists did not prevent the increase in MEPSC frequency induced by mAChRs (Fig. 4B; nonpaired $t$ test, $p=0.3)$. Similar changes in mEPSP frequency were observed in current-clamp recordings $(n=15$ for OxoM; $n=13$ for DHPG; data not shown).

Conversely, the group I mGluR agonist DHPG $(5 \mu \mathrm{M})$ increased mEPSC frequency from $7.5 \pm 1.6 \mathrm{~Hz}$ to $12 \pm 3.4 \mathrm{~Hz}$ (Fig. $4 C, D$; $n=6$; increase of $50 \pm 19 \% ; p=0.024$, paired $t$ test). In the presence of the M1 mAChR antagonist telenzepine (75 nM), DHPG increased the mEPSC frequency from $6.2 \pm 2.1 \mathrm{~Hz}$ to $9.0 \pm 3.0 \mathrm{~Hz}$ (Fig. $4 C, D ; n=$ 5 ; increase of $46 \pm 16 \% ; p=0.018$, paired $t$ test). Thus the mAChR antagonist had no significant effect on the mGluR-mediated increase in mEPSC frequency (Fig. $4 D$, nonpaired $t$ test, $p=0.9$ ). Similarly, no difference was detected when mEPSPs were recorded in current clamp $(n=8)$.

In whole-cell recordings from stratum oriens interneurons, amplitude distributions of miniature EPSCs (range 5-30 pA) were not altered by either OxoM or DHPG $(t$ test, $p=0.12$ for DHPG; $p=$
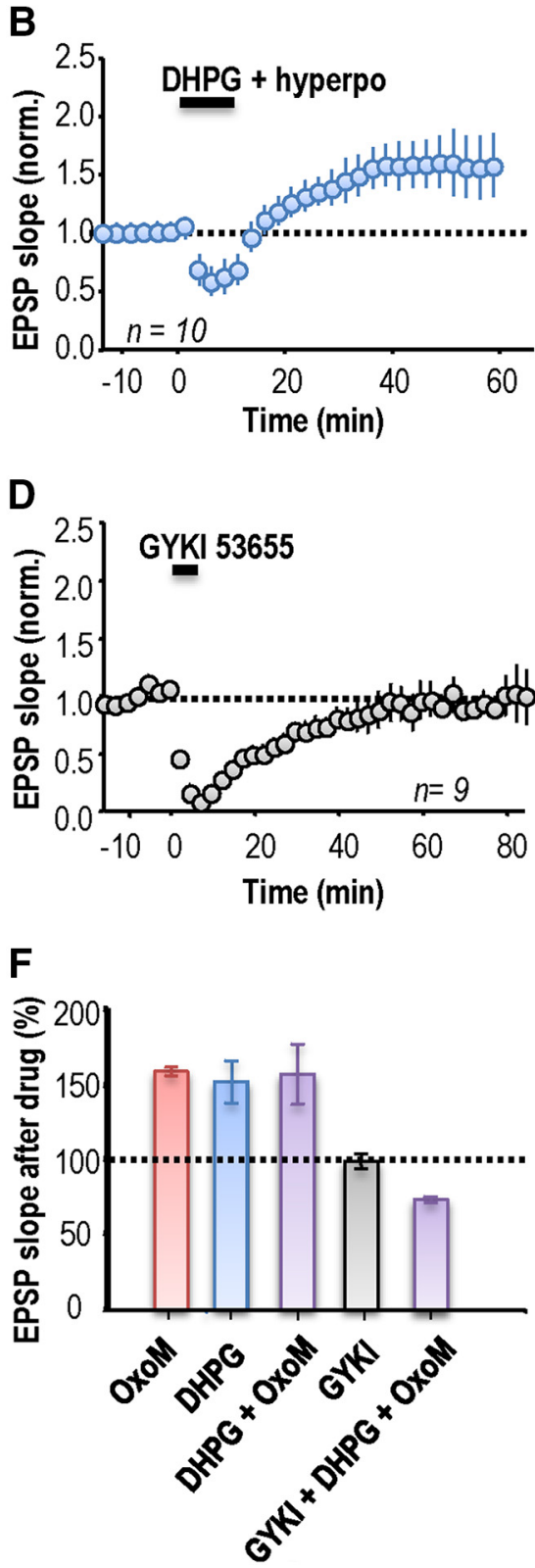

Figure 2. $m A C h R s$ and group I mGluR agonists induce anti-Hebbian LTP in stratum oriens interneurons. $A$, Activation of $\mathrm{mAChRs}$ with the agonist $0 \times 0 \mathrm{M}(5 \mu \mathrm{m} ; 10 \mathrm{~min}$ ) coupled with postsynaptic hyperpolarization induced an LTP of EPSP slope. $\boldsymbol{B}$, Activation of type I mGluRs by the agonist DHPG (5 $\mu \mathrm{m} ; 10 \mathrm{~min})$ together with a hyperpolarization induced an LTP of similar amplitude after a transient ( $~ 10 \mathrm{~min}$ ) synaptic depression. C, Activating both mAChRs and type I mGluRs induced a transient EPSP depression of longer duration followed by a delayed LTP. D, The antagonist GYKI 53655 ( $25 \mu \mathrm{M}, 5-7 \mathrm{~min})$ completely and reversibly blocked EPSPS. $E$, LTP did not result when the agonists 0xoM and DHPG were applied during the suppression of EPSPs by GYKI 53655. F, Summary of changes in EPSP slope at 40 min after drug application. Error bars show SEM. $\boldsymbol{A}-\boldsymbol{E}$, Each symbol represents an average of EPSP slopes from 20 events elicited at 15 s intervals and error bars show SEM. Time $t=0$ corresponds to the induction procedure.

0.84 for OxoM; data not shown). Similarly mEPSC amplitudes were not affected by group I mGluR or mAChR antagonists. These changes in mEPSC frequency (Fig. $4 B, D$ ) show that mAChRs and group I mGluRs are both expressed at excitatory terminals. However, they provide no evidence for interactions between the GPCR signaling systems at this site.

Postsynaptic crossed antagonism at M1 mACh and group I mGlu receptorss

We next looked for crossed antagonist effects at mAChRs and group I mGluRs expressed by postsynaptic interneurons. Activa- 
A
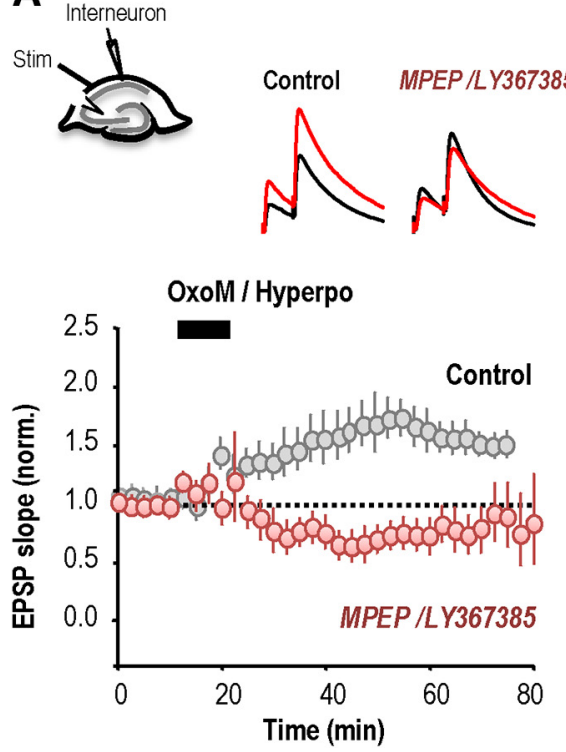

B

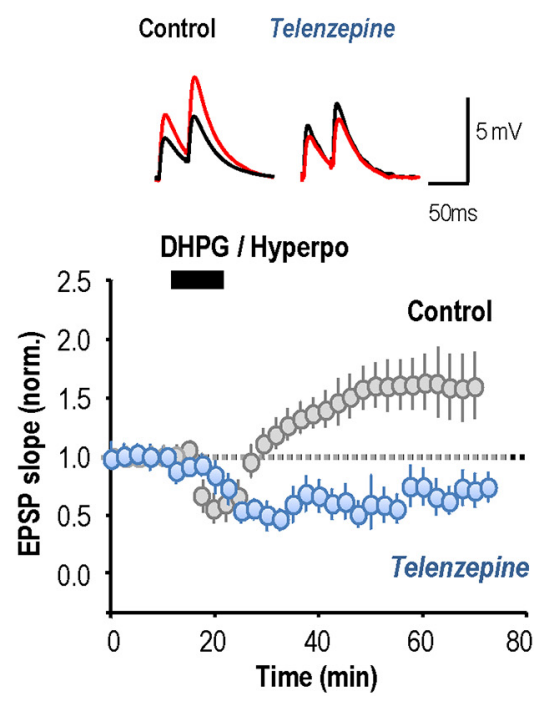

Figure 3. Crossed antagonism between muscarinic and group I mGlu receptors. A, LTP induced by 0xoM ( $5 \mu \mathrm{m}$; gray circles) coupled to a postsynaptic hyperpolarization, was suppressed by the mGluR1/5 antagonists MPEP and LY367385 (red circles). Top, Schematic showing the arrangement of stimulating and recording electrodes. Inset, Representative sample traces from a single neuron before (black) and after (red) the pharmacological activation of the $\mathrm{mAChR}$ paired with a postsynaptic hyperpolarization. $B$, The LTP induced by coupling postsynaptic hyperpolarization and the type I mGluR agonist, DHPG (gray circles), was suppressed by the application of the mAChR antagonist telenzepine ( $75 \mathrm{~nm}$; blue circles). Inset, Representative sample traces from a single neuron before (black) and after (red) the pharmacological activation of the $m G$ luR paired with a postsynaptic hyperpolarization. Symbols in $\boldsymbol{A}$ and $\boldsymbol{B}$ represent an average of EPSP slope from 20 events elicited at $15 \mathrm{~s}$ intervals and the bars show SEM. Time $t=0$ corresponds to the induction procedure.

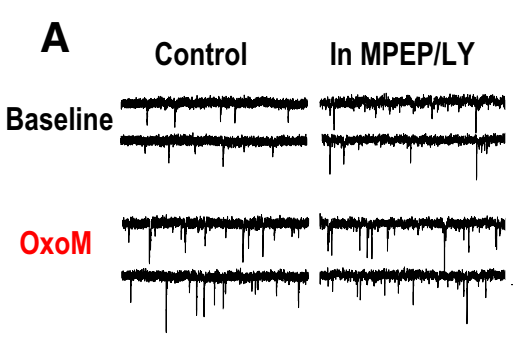

B

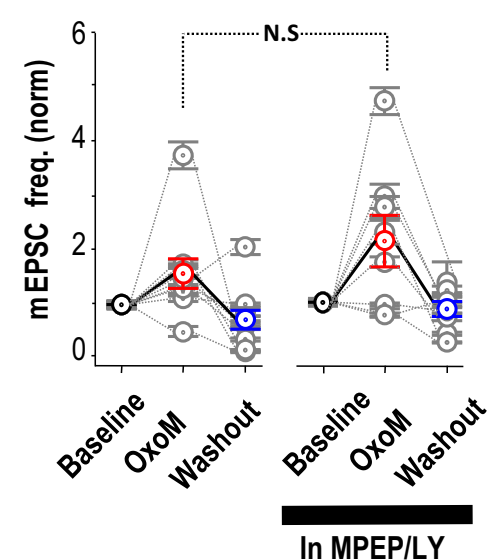

C

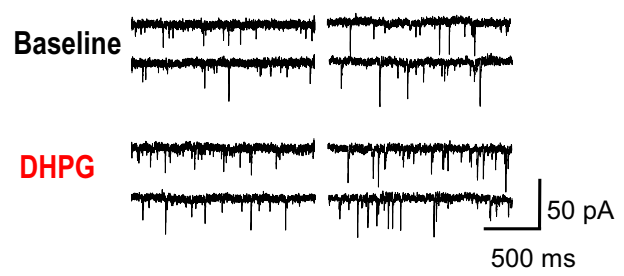

D

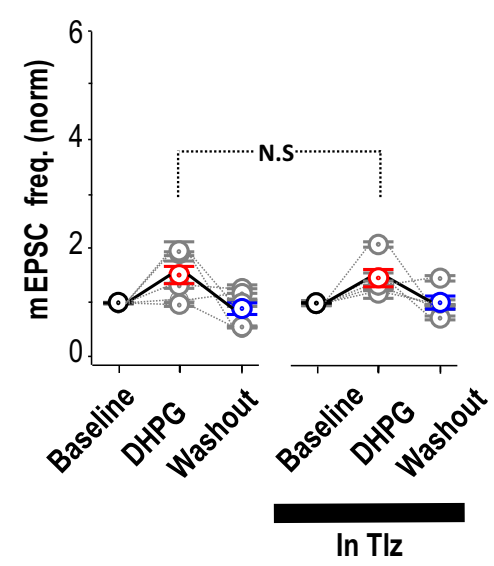

Figure 4. No evidence for presynaptic cross talk between M1 mAChR and group I mGluR on miniature EPSCs. $A, B$, Effect of activating $\mathrm{mAChRs}$ with $0 \mathrm{XOM}(5 \mu \mathrm{M})$ on $\mathrm{mEPSC}$ recorded in the presence of TTX $(1 \mu \mathrm{m})$. $A$, Increase in $\mathrm{mEPSC}$ frequency induced by $0 \times 0 M$ in control conditions and under blockade of mGluR I by MPEP and LY367386. B. There was no difference in the increase in miniature frequency induced by 0xoM in the absence and the presence of LY367386 and MPEP ( $n=8$ neurons). C, D, Effect of activating group I mGluR on mEPSCS. C, Increase in mEPSC frequency induced by the group I mGluR agonist DHPG (5 $\mu \mathrm{m})$ in control conditions and under blockade of $\mathrm{mAChRs}$ by telenzepine. $\boldsymbol{D}$, The increase in $\mathrm{mEPSC}$ frequency induced by DHPG was similar in the presence or the absence of telenzepine $(n=5)$.

tion of either receptor affects transient and persistent $\mathrm{K}^{+}$currents. We tested possible effects on the voltage trajectory after interneuron firing (Benardo and Prince, 1982; Greene et al., 1994; Kawasaki et al., 1999; McQuiston and Madison, 1999; Ireland and Abraham, 2002) and on the steady-state membrane potential (Cole and Nicoll, 1983; Madison et al., 1987; Crépel et al., 1994; Guérineau et al., 1995; Howe and Surmeier, 1995; Mannaioni et al., 2001; Lawrence et al., 2006a).

We first examined actions of group I mGluR and mAChR activation on the AHP that follows repeated action potentials (Park and Spruston, 2012). In perforated patch recordings from stratum oriens interneurons maintained at -60 $\mathrm{mV}$, five action potentials were induced by currents injected at interval $2 \mathrm{~ms}$. They were followed by an AHP with time to peak of 5-50 ms, ( $n=48$ of 51 cells; Fig. $5 A, B)$.

The mAChR agonist OxoM ( $5 \mu \mathrm{M})$ reduced the amplitude of the hyperpolarization following bursts of five action potentials (Fig. $5 A, C, E, F$ ) but only converted an AHP into a depolarizing afterpotential (DAP) in a minority of stratum oriens interneurons (cf. Lawrence et al., 2006b). After-potentials were measured as the difference in membrane potential before and $50 \mathrm{~ms}$ after firing. OxoM induced a mean shift in this difference of $+2.6 \pm 0.9 \mathrm{mV}$, from a postburst potential of $-4.1 \pm 0.8$ to $-1.4 \pm 1 \mathrm{mV}(n=$ 25; Fig. 5C,E,F). Applied in the presence of the group I mGluR antagonists, MPEP $(25 \mu \mathrm{M})$ and LY367386 $(100 \mu \mathrm{M})$, OxoM induced a shift in potential of $2.7 \pm 0.8$ $\mathrm{mV}$ (Fig. 5C,E,F). Thus mGluR antagonists did not affect the postburst polarization induced by OxoM ( $t$ test, $p=0.8$; Fig. 5E).

The group I mGluR agonist DHPG (2 $\mu \mathrm{M})$ typically reduced the postburst AHP in oriens interneurons and sometimes converted an AHP into a DAP (Fig. $5 B, F)$. Applied alone, DHPG induced a mean shift in potential of $3 \pm 1.4 \mathrm{mV}$ at 50 ms after firing $(n=24$; Fig. $5 D, F)$. In the presence of the M1 mAChR antagonist telenzepine $(75 \mathrm{nM})$, the shift induced by DHPG was $4.0 \pm 1.6 \mathrm{mV}(t$ test, $p=0.497$; Fig. $5 D-F)$.

In conclusion, antagonists of one GPCR did not affect the actions of agonists of the other receptor on the membrane potential trajectory after interneuron burst firing.

In contrast we did detect crossed antagonist effects in long-term actions of these GPCRs on interneuron membrane potential. In current-clamp recordings 
made in perforated patch mode, bath application of the mGluR agonist DHPG $(5 \mu \mathrm{M}, 10 \mathrm{~min})$ caused an acute depolarization of $12.5 \pm 5 \mathrm{mV}$ (paired $t$ test, $p=0.038, n=9$; Fig. $6 A, A 2$ ), followed by a rebound hyperpolarization. Neurons were still hyperpolarized 30 min later, by $3.0 \pm 0.9 \mathrm{mV}$ from $-76.2 \pm 4$ to $-79.4 \pm 4 \mathrm{mV}$ (paired $t$ test, $p=0.01)$. When DHPG was applied in the presence of the cholinergic antagonist telenzepine (75 $\mathrm{nm})$, it induced a similar initial depolarization of $13.0 \pm 3.0 \mathrm{mV}$ (paired $t$ test, $p=0.006$, $n=8)$. However there was no consistent long-term hyperpolarization $(72 \pm 2.2$ to $-69 \pm 3.1 \mathrm{mV})$ of membrane potential at $30 \mathrm{~min}$ after washout $(n=8$, nonpaired $t$ test, $p=0.105)$. Thus, as for the effects on LTP induction, the mAChR antagonist affects the long-term actions of a group I mGluR agonist on interneuron membrane potential.

In reciprocal experiments OxoM (5 $\mu \mathrm{M}, 10 \mathrm{~min}$ application; Fig. $6 B, B 2)$ induced a peak acute interneuron depolarization of $5.6 \pm 2.2 \mathrm{mV}(n=6$; paired $t$ test, $p=0.04$ ) and a small nonsignificant hyperpolarization (from $-83.3 \pm$ $2.9 \mathrm{mV}$ at baseline to $-85.5 \pm 3.5 \mathrm{mV}$ ) at $30 \mathrm{~min}(n=6$; paired $t$ test, $p=1)$. Repeated in the presence of the group I mGluR receptor antagonists MPEP (10 $\mu \mathrm{M})$ and LY367386 (100 $\mu \mathrm{M})$, OxoM application induced a similar acute depolarization of $5 \pm 1.8 \mathrm{mV}$ (paired $t$ test, $p=0.03, n=6$ ). However a persistent change in potential of $10 \pm 1.8 \mathrm{mV}$ (from $-87 \pm 2.8 \mathrm{mV}$ at baseline to$77 \pm 3 \mathrm{mV}$ ) was maintained at $30 \mathrm{~min}$ after washout $(n=6$; paired $t$ test, $p=$ 0.017). These data suggest that antagonists of either mAChR (M1) or mGluR (group I) can alter persistent actions on interneuron membrane potential induced by agonists at the other GPCR.

Interneuron membrane potential was not clamped to negative potentials during agonist application in the experiments shown in Figure 6A2 and B2. We next asked how this procedure, which should enhance $\mathrm{Ca}^{2+}$ entry via AMPARs expressed by interneurons, affected longterm changes in their membrane potential. OxoM application coupled with interneuron hyperpolarization increased EPSP slope but did not induce a significant long-term change in membrane potential (from $-73.8 \pm 2.2 \mathrm{mV}$, at $60 \mathrm{~min}$ after OxoM -75.3 $\pm 2.4 \mathrm{mV} ; n=7, p=0.148$; Fig. 6B1,B3). Repeating OxoM application in the presence of LY367386 and MPEP induced no long-term change in membrane potential (before OxoM $-72.6 \pm 0.9 \mathrm{mV}$, at $60 \mathrm{~min}$ after OxoM $-73.4 \pm 1.2 \mathrm{mV} ; n=7, p=0.67$; Fig. 6 B1,B3). DHPG coupled with interneuron hyperpolarization did not induce a persistent change in interneuron membrane potential whether it

B

MPEP + LY
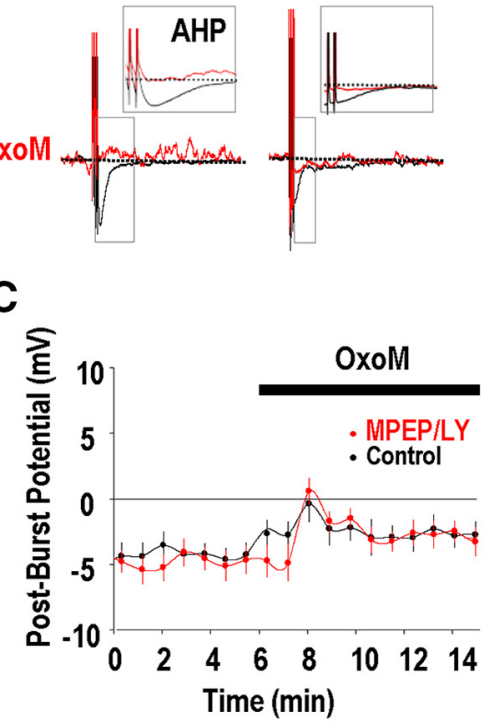

E

Figure 5. No evidence for postsynaptic cross talk between M1 AChRs and group I mGluRs effects on AHPs. AHPs were induced by initiating five action potentials at interval $2 \mathrm{~ms}(\boldsymbol{A}, \boldsymbol{B}$, black traces). $\boldsymbol{A}$, A reduction in amplitude of the AHP induced by the races). $\boldsymbol{B}$, The group I mGluR agonist DHPG (5 $\mu \mathrm{m})$ transformed a hyperpolarizing afterpotential into a depolarizing afterpotentia . Influence of the M1 mAChR antagonist Telenzepine on the actions of DHPG.C,MPEP and LY367386 had little effect on the AHP eabsence and then in the presence of telenzepine ( $n=24$ cells). E, Summary of changes in the postburst potential induced by oxotremorine and DHPG in the absence and presence of $\mathrm{mGluR}$ and $\mathrm{mAChR}$ antagonists respectively. $F$, Mean changes in postburst potentials induced by $0 \times 0 M$ and DHPG in the absence and presence of MPEP and LY367386 and telenzepine, respectively. was applied alone or in the presence of telenzepine (paired $t$ test, $p=0.95, n=10$; Fig. $6 A 1, A 3)$.

\section{Properties of synapses expressing anti-Hebbian plasticity}

Most excitatory synapses on stratum oriens interneurons are made by CA1 pyramidal cells (Blasco-Ibáñez and Freund, 1995). Because extracellular stimulation has been used in most studies, LTP of these synapses has not been examined in isolation in paired recordings. We recorded from synaptically coupled pyramidal cells and stratum oriens interneurons (Ali and Thomson, 1998; Losonczy et al., 2002) to characterize this synapse and the factors controlling its long-term plasticity (Fig. 7).

Action potentials were induced in CA1 pyramidal cells recorded in whole-cell $(n=22)$ or cell attached $(n=12)$ modes. EPSPs evoked in stratum oriens interneurons (Fig. $7 B$ ) were recorded in whole-cell $(n=11)$ or perforated patch mode $(n=23)$. 

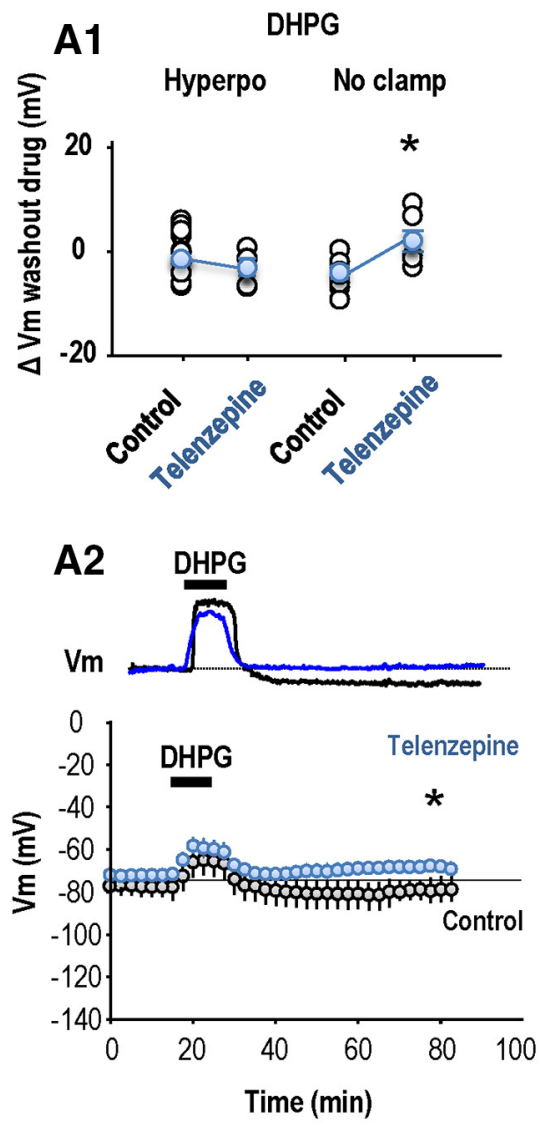

A3

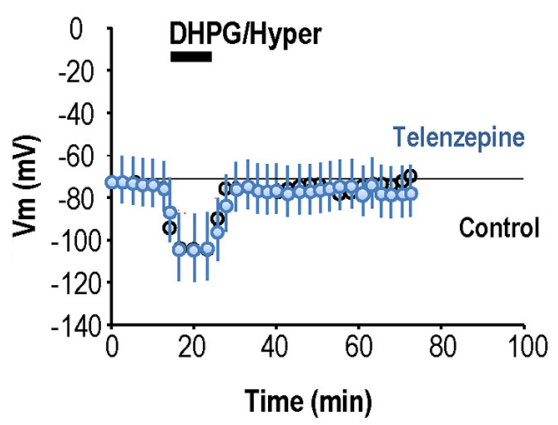

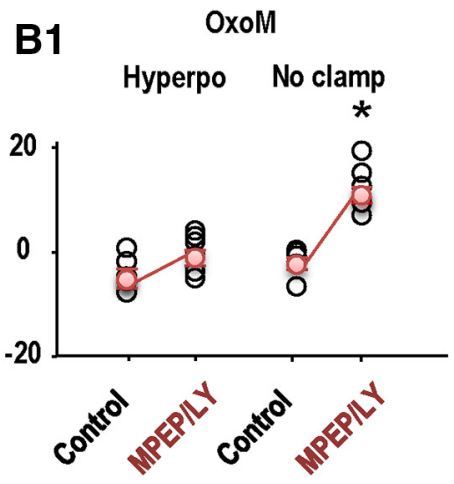

B2
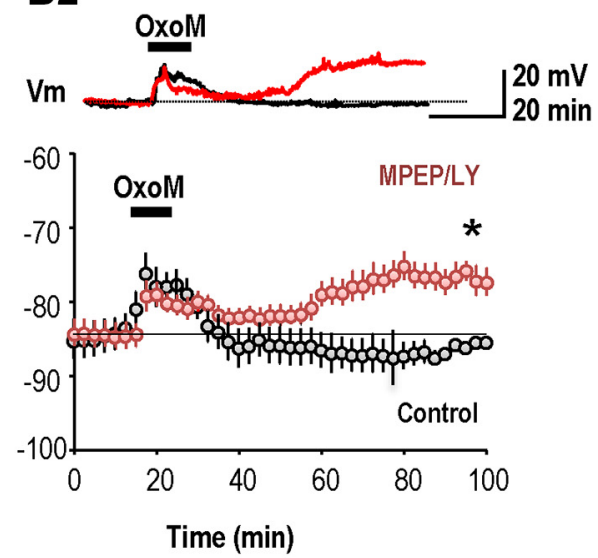

B3

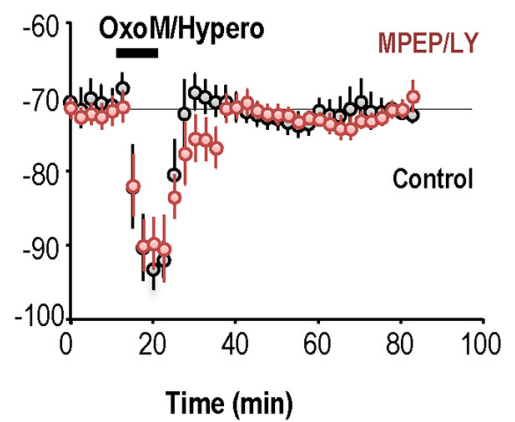

Figure 6. Cross talk between effects of group I mGluRs and M1 AChRs on interneuron membrane potential. A1, Summary of mean persistent change in membrane potential of interneurons after application of DHPG (10 min, $5 \mu \mathrm{M})$ in the absence and in the presence of the M1 mAChR antagonist telenzepine. A2, A persistent long-term hyperpolarization was evident at 30 min after DHPG application when the $V_{\mathrm{m}}$ was not clamped ( $n=9 ; p=0.01$, paired $t$ test, black points). This persistent hyperpolarization was abolished when DHPG was applied in the presence of the M1 mAChR antagonist telenzepine ( $n=8$; blue points). Top, Representative traces are shown from single interneurons. A3, No long-term changes of membrane potential were detected when the interneuron was hyperpolarized during the DHPG application. B1, Summary of mean persistent change in membrane potential of interneurons induced by 0xoM (10 min, $5 \mu \mathrm{M}$ ) in the absence and later in the presence of the group I mGluR antagonists MPEP and LY367386. B2, A persistent depolarization occurred when group I mGluR antagonists were present and the membrane potential was not clamped ( $n=6$ neurons; $p<0.01$, paired $t$ test, red points). Top, Representative traces are shown from single interneurons. $B 3$, No persistent change in membrane potential occurred when the interneuron was hyperpolarized during 0xoM application $(n=7)$. In $\mathbf{A 2}, \boldsymbol{A 3}, \boldsymbol{B} \mathbf{2}$, and $\mathbf{B} \mathbf{3}$ each symbol is a mean $V_{\mathrm{m}}$ value from 20 measurements at $15 \mathrm{~s}$ intervals. Bars show SEM.

The proportion of EPSPs elicited by single presynaptic action potentials ranged between 3 and $100 \%$ at different pairs. The remaining trials, when action potentials elicited responses indistinguishable from the noise, were classed as failures of transmission ( $n=34$; Fig. $7 C, D)$. The mean amplitude of all evoked events varied between 0.3 and $8 \mathrm{mV}(1.26 \pm 0.23 \mathrm{mV}, n=20$; Fig. $7 C)$.
EPSPs typically facilitated in response to a second action potential at short interval (5-50 ms; Fig. 7E). The mean PPR for a second EPSP induced at an interval of 20 ms was $160 \pm 27 \%(n=8)$. EPSPs recorded at $-60 \mathrm{mV}$ (Fig. $7 F$ ), decayed with an exponential time constant between 15 and $35 \mathrm{~ms}$ (mean $26.4 \pm 6 \mathrm{~ms}$, $n=6)$. Hyperpolarization from -60 to $-90 \mathrm{mV}$, as during LTP induction, acutely increased EPSP amplitude by $40 \pm 14 \%$ ( $n=4$ pairs, averages of 30 or more EPSPs; Fig. $7 F$ ). The decay time constant was prolonged from 9.1 to 24 $\mathrm{ms}$ at $-90 \mathrm{mV}$ for one unitary EPSP, but only minor voltage-dependent changes were apparent for the other EPSPs.

\section{Expression sites of plasticity at excitatory synapses onto stratum oriens interneurons}

Long-term plasticity of these excitatory synapses was examined using several different protocols. We first asked whether persistent changes in synaptic efficacy could be induced by stimulating a single presynaptic pyramidal cell at high-frequency $(100 \mathrm{~Hz}$; 100 spikes) while hyperpolarizing the postsynaptic interneuron to -90 to $-100 \mathrm{mV}$. At $20 \mathrm{~min}$ after this induction procedure, the mean amplitude of unitary EPSPs was reduced in 7 of 14 pairs tested $(42 \pm 6 \%$ ) and changed by $<10 \%$ for the other seven pairs.

Reasoning that stimulating single pyramidal cells may not activate GPCRs, we used paired recordings to look for changes at excitatory synapses during pharmacologically induced plasticity (compare Figs. $8,2)$. Pyramidal cells were recorded in whole-cell mode and OxoM $(5 \mu \mathrm{M})$ was applied for $5 \mathrm{~min}$. Postsynaptic interneurons were recorded in the perforated patch mode because perturbation of the internal milieu suppresses anti-Hebbian LTP (Fig. 8A2). Postsynaptic cells were hyperpolarized during GPCR agonist application and LTP occurrence was tested in response to stimulating afferents extracellularly (Fig. 8A1), as well as in response to action potentials in a single CA1 pyramidal cell (Fig. 8A2). In five experiments, a mean increase in EPSP slope of $128 \pm 9 \%$ was evoked at 30 min after induction at the synapses activated by fiber stimulation (eEPSP; paired $t$ test; $p=0.04$; Fig. $8 A 1$ ). However, unitary EPSPs recorded at the same time were not potentiated. Mean unitary EPSP amplitude was depressed at $30 \mathrm{~min}$ in three of five pairs and did not change in the other two pairs (paired $t$ test; $p=0.62$; Fig. 8A2).

Finally, we asked whether pharmacologically induced LTP might be sensitive to perturbation of the internal medium of the 
presynaptic pyramidal cell. To avoid cytoplasmic dialysis, presynaptic cells $(n=9)$ were recorded in cell-attached rather than whole-cell mode (Fig. 8B). Unitary EPSPs were induced by single or repetitive presynaptic action potentials. Responses to extracellular fiber stimulation were recorded in parallel to test whether synaptic potentiation was elicited (Fig. 8B1). In three of nine experiments using this protocol, neither EPSPs induced by fiber stimulation nor unitary EPSPs exhibited LTP. In the other six experiments however, both afferent and unitary EPSPs were potentiated at $30 \mathrm{~min}$ after induction. The slope of afferent EPSPs increased by $75 \pm 15 \%$ (Fig. $8 B 1$ ), and in parallel, the mean amplitude of all responses, including failures, induced by single CA1 pyramidal cells increased by $49 \pm 3 \%$ (Fig. 8B2).

Analysis of trial-to-trial fluctuations of unitary responses may resolve presynaptic and postsynaptic contributions to enhanced synaptic efficacy. In four of six paired recordings where unitary EPSPs were potentiated, transmission failures were detected (Fig. 8) before the antiHebbian protocol was applied: the proportion of failures decreased from $30 \pm 5$ to $15 \pm 4 \%$ of trials $(n=4)$ at $30-50 \mathrm{~min}$ after LTP induction. The amplitude of evoked EPSPs (Fig. 8) changed from $1.1 \pm$ 0.2 to $1.7 \pm 0.3 \mathrm{mV}$ at $30-50 \mathrm{~min}$ after induction. A mean increase of $49 \%$ in amplitude of evoked EPSPs was not statistically significant (paired $t$ test, $p=0.159$ ). Finally the PPR of EPSPs induced by two presynaptic action potentials at $50 \mathrm{~ms}$ interval increased by $21 \pm 3 \%$ in four pairs and decreased by $17.5 \pm 1.8 \%$ in the other two pairs. Although preliminary, these findings are consistent with a presynaptic increase in neurotransmitter release.

\section{Discussion}

The present study shows that group I mGluRs and $\mathrm{mAChRs}$ are both involved in the induction of LTP at synapses that excite stratum oriens interneurons. Antagonists of either receptor suppressed persistent changes in synaptic efficacy elicited by agonists of the other receptor pointing to a cooperative action. A similar cross talk was evident in the persistent effects of mGluRs and mAChRs on interneuron membrane potential, but not in their effects on the frequency of miniature EPSPs or on the afterhyperpolarization elicited by bursts of action potentials. Recordings from single excitatory connections suggest that LTP depends, at least in part, on an increase in transmitter release. If the interactions involved in LTP induction occur postsynaptically, then a signal is presumably transmitted to enhance release from presynaptic terminals.

\section{LTP induction requires activation of $\mathrm{mGluR}$ and $\mathrm{mAChRs}$}

The present data show that activation of $\mathrm{M} 1 \mathrm{mAChRs}$ is required to induce anti-Hebbian LTP (Fig. 1). This form of LTP is typically
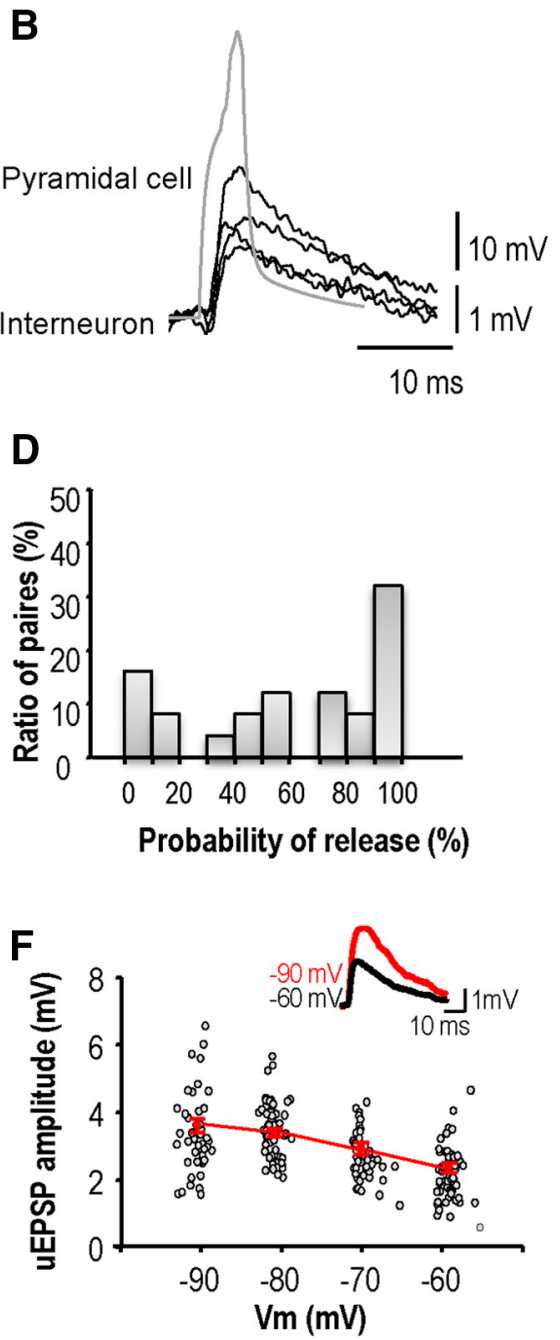

Figure 7. Unitary EPSPs evoked in stratum oriens interneurons by CA1 pyramidal cells. $\boldsymbol{A}$, Image of pipettes recording from presynaptic CA1 pyramidal cell and postsynaptic interneuron. $\boldsymbol{B}$, EPSPs induced in an interneuron by single action potentials of a ( connections varied from high to low. $E$, Paired-pulse facilitation was typical for EPSPs initiated by the second of two presynaptic 30-200 ms. F, Postsynaptichyperpolarization from -60 to $-100 \mathrm{mV}$, increased the amplitude of unitary EPSPs. graph shows the amplitude of all EPSPs $(n=122)$ recorded from one pair at potentials between -93 and $-58 \mathrm{mV}$. Inset, Averaged EPSPs $(n=50)$ recorded at $-60 \mathrm{mV}$ (black) and $-90 \mathrm{mV}(\mathrm{red})$.

induced by high-frequency extracellular stimulation in stratum oriens although it can also be elicited by pairing $5 \mathrm{~Hz}$ stimulation with postsynaptic hyperpolarization (Lamsa et al., 2007). A related form of LTP can be elicited by extracellular theta-burst stimulation (Perez et al., 2001). Such stimulation protocols are likely to excite cholinergic axons and activate mAChRs (Cole and Nicoll, 1984), which are moreover tonically active in hippocampal slices. Muscarinic receptor activation is then part of a triple requirement for LTP induction. mGluRs have been also implicated in long-term plasticity at excitatory synapses made with oriens interneurons (Perez et al., 2001; Topolnik et al., 2006) and their activation is required to induce anti-Hebbian LTP (Lamsa et al., 2007; Le Duigou and Kullmann, 2011). The necessity for activation of $\mathrm{Ca}^{2+}$-permeable AMPARs has been firmly established at this (Lamsa et al., 2007; Oren et al., 2009) and other excitatory synapses made with other hippocampal interneurons (Le Roux et al., 2013; Hainmüller et al., 2014). Our data show that this form of plasticity could be induced chemically when mGluR and mAChR 

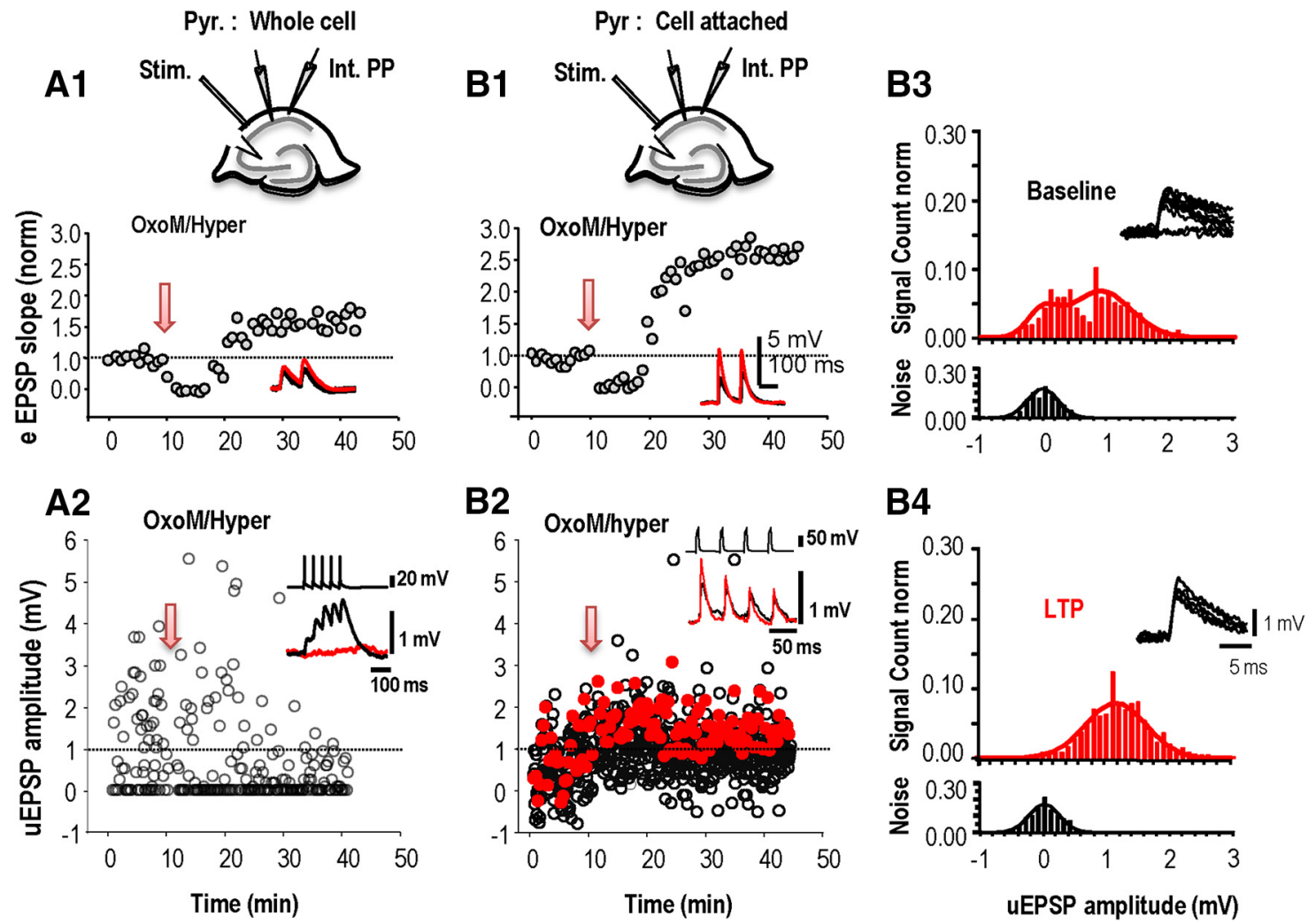

Figure 8. Long-term potentiation of unitary EPSCs induced in oriens interneuron. Responses of an interneuron to fiber stimulation in stratum oriens $(\boldsymbol{A 1}, \boldsymbol{B} 1)$ were recorded in parallel with unitary events evoked by a CA1 pyramidal cell $(\boldsymbol{A 2}, \boldsymbol{B} 2)$ before and after activation of mAChRs $(0 \times 0 \mathrm{M})$. The presynaptic pyramidal cell was recorded in whole-cell mode $(\boldsymbol{A})$ or in cell-attached mode $(\boldsymbol{B})$ to avoid the cytoplasm dialysis. $\boldsymbol{A 1}$, EPSPs induced in the interneuron by fiber stimulation were depressed before a long-term potentiation emerged. $\boldsymbol{A 2}$, From the same experiment as $\boldsymbol{A 1}$, unitary EPSPs induced in the interneuron showed a maintained depression when CA1 pyramidal cell action potentials were induced in whole-cell recording mode. B1, Sequence of depression followed by long-term potentiation of afferent EPSPs induced by activation of $\mathrm{mAChRs}(0 \mathrm{xOM})$. $\boldsymbol{B} 2$, Same experiment as $\boldsymbol{B}$, unitary EPSPs showed a maintained potentiation when CA1 pyramidal cell action potentials were induced in a cell-attached record. $\boldsymbol{A} 1$ and $\boldsymbol{B} 1$ show EPSP slope averaged $>20$ events elicited at 15 s intervals. $\boldsymbol{A} \mathbf{2}$ and $\boldsymbol{B} 2$ show amplitudes of all unitary EPSPs evoked at 15 sintervals. B3, B4, Amplitude distributions for unitary events (red, top) elicited in an interneuron by pyramidal cell action potentials and of the noise (black, bottom) measured as described in Materials and Methods. Data were obtained from 256 trials at -15 to 0 min before and from 640 trials at $20-40$ min after the potentiation protocol. A Gaussian fit to the noise amplitude had a mean of $0.03 \pm$ $0.23 \mathrm{mV}$ before and $0.01 \pm 0.24 \mathrm{mV}$ after potentiation. From a double-Gaussian fit to events evoked by action potentials, the proportion of failures was reduced from 0.205 to 0.002 . The synaptic efficacy, or amplitude of evoked EPSPs, was $0.8 \pm 0.4 \mathrm{mV}$ before and $1.27 \pm 0.7 \mathrm{mV}$ after plasticity was induced. Insets in $\boldsymbol{B} 3$ and $\boldsymbol{B} 4$ show overlays of 10 responses induced before and after LTP.

activation was coupled to interneuron hyperpolarization (Fig. 2). However, the suppression by antagonists of either receptor (Fig. 3) of pharmacologically induced LTP was surprising and may point to a deeper cooperation or synergy between mGluRs and mAChRs. Furthermore we detected a long-term plasticity of interneuron membrane potential (Fig. 6), which also required a cooperation between these two GPCRs but without a necessity for interneuron hyperpolarization. Activation of group I mGluRs and /or M1 mAChRs may induce bidirectional synaptic plasticity (Palmer et al., 1997; Volk et al., 2007; Kamsler et al., 2010). In this study preventing activation of either GPCR (Fig. $3 A, B$ ) produced a synaptic depression. However, when both GPCRs and AMPARs (Fig. 2D,E) were activated and the interneuron membrane potential was hyperpolarized, synaptic potentiation was revealed.

\section{Interactions between group I mGluRs and M1 mAChRs}

Group I mGluRs and M1 mAChRs modulate both neuronal excitability (van Hooft et al., 2000; Lawrence et al., 2006b; Park and Spruston, 2012) and synaptic function (Auerbach and Segal, 1996; Palmer et al., 1997), via the Gq protein subunit and downstream pathways. Activation of these receptors has also been implication in the induction of long-term depression at Schaffer collateral synapses made with CA1 pyramidal cells (Volk et al., 2007; Kamsler et al., 2010) and in the short-term depression of synaptic inhibition induced by postsynaptic depolarization (Edwards et al., 2006). Here we detected cooperative interactions between mGluRs and mAChRs (Fig. 3) in the induction of LTP of EPSPs at synapses made with interneurons. A similar cooperation was evident in the control of interneuron membrane potential, in that antagonists of type I mGluRs suppressed the actions of $\mathrm{mAChR}$ agonists and vice versa (Fig. 6). Such cooperation could involve the modulation of multiple conductances including the M-current $\left(I_{\mathrm{M}}\right)$, a calcium-activated potassium conductance $\left(I_{\mathrm{AHP}}\right)$ mediated by SK channels or a calcium-dependent cationic conductance $\left(I_{\mathrm{CAT}}\right.$; Lawrence et al., 2006a; Buchanan et al., 2010; Giessel and Sabatini, 2010). Arguing against nonspecific pharmacological actions, such crossed actions were not evident in effects on miniature EPSC frequency induced by mGluRs and mAChRs (Fig. 4) nor on effects on afterpotentials induced by interneuron firing (Fig. 5).

Such cooperation between mGluRs and mAchRs could arise at multiple sites, from G-protein activation, through second messenger pathways to effector sites, or even at the receptors. Thus, muscarinic M1 and glutamatergic mGluR5 signals cooperate in the induction of cortical LTD (Choi et al., 2005), whereas adrenergic $\alpha$ land glutamatergic mGluR1 signals converge on $\mathrm{Gq}$ to induce LTD at synapses made by hippocampal Schaffer collaterals (Scheiderer et al., 2008). Alternatively antagonists at one re- 
ceptor might suppress tonic actions on a second messenger system common to both. Thus, eliminating tonic actions of mAChR on intracellular PKC levels can block an mGluRmediated LTD of EPSPs terminating on CA1 pyramidal cells (Kamsler et al., 2010). Functionally similar effects might occur if GPCR antagonists act as inverse agonists to reduce a tonic activity of molecules mediating the actions of mGluRs and mAChRs. Indeed MPEP, but not MCPG, has inverse agonist actions at group I mGluRs and atropine, but apparently not telenzepine, inhibits M1 type mAChRs as an inverse agonist (Davis et al., 2009). Intracellular cooperation at the same or in different pathways could induce additive or supralinear effects on an intracellular component of LTP induction pathways, as for the synergistic actions of $\mathrm{mGluR}$ and $\mathrm{mAChR}$ activation on afterpotentials in CA1 pyramidal cells (Park and Spruston, 2012). Alternatively cooperation might involve functional hetero-dimers of GPCR (Watts et al., 2013). If so, downstream actions of potential mGluRI-mAChR heterodimers should be blocked by antagonists at both receptors. Distinct populations of mGluR and $\mathrm{mAChR}$ homodimers would also be needed to account for effects on transmitter release (Fig. 4) and on postfiring afterpotentials (Fig. 5) that were not suppressed by antagonists at the other receptor.

Expression site for anti-Hebbian LTP from dual recordings. How might postsynaptic interactions between mGluR, mAChR and $\mathrm{Ca}^{2+}$-permeable AMPARs induce LTP? Although we showed mGluRs and $\mathrm{mAChRs}$ cooperate to induce anti-Hebbian LTP, we also detected cooperative actions of these receptors in a long-term hyperpolarization of interneurons. We note that this long-term effect (Campanac et al., 2013) also required the activation of $\mathrm{Ca}^{2+}$-permeable AMPARs, because an opposing change in membrane potential occurred when interneurons were not hyperpolarized (compare Figs. 6, 3). A persistent interneuron hyperpolarization might increase EPSP amplitude, although interneuron membrane potential was maintained in a relatively stable potential range during LTP expression (Fig. 3). It is harder to explain how changes in postsynaptic potential could directly influence transmitter release.

Recordings of synaptic events induced by one neuron in another have provided special insights into LTP expression (Debanne et al., 1999; Pavlidis et al., 2000; Zilberter et al., 2009). Paired recordings made in this work show that excitatory synapses between CA1 pyramidal cells and stratum oriens interneurons can exhibit LTP (Fig. 8). They however show that both presynaptic and postsynaptic sites are sensitive to dialysis of effectors necessary to induce or maintain LTP. Persistent synaptic changes were only apparent when the presynaptic cell was excited via cell attached recordings and the postsynaptic cell was recorded in perforated patch mode.

Changes in the short-term plasticity and a reduced number of probable failures of minimally evoked EPSPs suggest presynaptic mechanisms may contribute to LTP expression at this synapse (Nicholson and Kullmann, 2014). Analysis of fluctuations in EPSPs induced by single CA1 pyramidal cells (Fig. 8) support presynaptic effects, but does not exclude additional changes in postsynaptic efficacy. EPSP amplitude distributions were fitted with one Gaussian curve centered at $0 \mathrm{mV}$ to describe instrumental and biological noise and a second Gaussian to describe evoked events. The proportion of transmission failures, defined by these distributions, suggests that these connections may involve one or few transmitter release sites (Gulyás et al., 1993). When persistent changes in mean EPSP amplitude were detected, the frequency of failures was consistently reduced. We also detected an increase of $49 \%$ in the mean amplitude of evoked events for four of six connections. This reduced number of failures suggests a presynaptic site of LTP expression. A decreased failure rate has, however, also been attributed to the insertion of AMPA receptors at previously "silent" synapses (Kullmann, 1994; Isaac et al., 1995; Liao et al., 1995), albeit for NMDAR-dependent LTP.

\section{Coupling between cooperative presynaptic induction and postsynaptic expression of LTP}

A retrograde messenger seems necessary to link induction processes that apparently involve cooperative interactions between mGluRs, mAChRs, and $\mathrm{Ca}^{2+}$-permeable AMPARs and an LTP expression with a clear presynaptic component. It is interesting that endocannabinoids released from pyramidal cells affect GABA release from interneuron terminals during the phenomenon of depolarization-induced suppression-of-inhibition (DSI; Wilson and Nicoll, 2001). Both mGluRs (Morishita et al., 1998) and M1 mAChRs (Kim et al., 2002) facilitate DSI, enhancing endocannabinoid synthesis and release via shared pathways, but it is not clear whether there are cooperative effects as this study suggests for LTP. However work with antagonists of possible retrograde messengers as nitric oxide and 12-(S)-HPETE acting on TRPV1 receptors (transient receptor potential vanilloid 1 channel) has so far failed to identify a plausible candidate (Nicholson and Kullmann, 2014). It may be worth pursuing distinct lipid signaling pathways that are activated by cooperative actions of mGluRs and M1 mAChRs.

\section{Functional implications of synergy during LTP induction}

These data suggest a triple requirement for LTP at excitatory synapses made with oriens interneurons. M1 mAChRs and type I mGluRs must be activated in conjunction with $\mathrm{Ca}^{2+}$ entry via $\mathrm{Ca}^{2+}$-permeable AMPARs of oriens interneurons. When might these requirements be met? During exploration, cholinergic systems are active and pyramidal cell firing induced by septal afferents could liberate sufficient glutamate to activate oriens cell mGluRs. A simultaneous oriens hyperpolarization to enhance anti-Hebbian $\mathrm{Ca}^{2+}$ may be mediated by inhibition from either septohippocampal cells (Blasco-Ibáñez and Freund, 1995; Chamberland et al., 2010; Tyan et al., 2014) and/or hippocampal VIP-containing cells (Acsády et al., 1996; Tyan et al., 2014). Verification of this hypothesis will require evidence that either or both of these interneuron cell types fire during cholinergic activation and that oriens cells are sufficiently hyperpolarized that anti-Hebbian LTP is induced. The consequence of LTP induction at this synapse would be a long-lasting increase in the inhibition of distal pyramidal cell dendrites. Functionally such a persistent change would tend to suppress inputs from the entorhinal cortex and favor the transmission of intrahippocampal information from CA3 (Leão et al., 2012).

\section{References}

Acsády L, Görcs TJ, Freund TF (1996) Different populations of vasoactive intestinal polypeptide-immunoreactive interneurons are specialized to control pyramidal cells or interneurons in the hippocampus. Neuroscience 73:317-334. CrossRef Medline

Ali AB, Thomson AM (1998) Facilitating pyramid to horizontal oriensalveus interneurone inputs: dual intracellular recordings in slices of rat hippocampus. J Physiol 507:185-199. CrossRef Medline

Auerbach JM, Segal M (1996) Muscarinic receptors mediating depression and long-term potentiation in rat hippocampus. J Physiol 492:479-493. CrossRef Medline

Baude A, Nusser Z, Roberts JD, Mulvihill E, McIlhinney RA, Somogyi P 
(1993) The metabotropic glutamate receptor (mGluR1 alpha) is concentrated at perisynaptic membrane of neuronal subpopulations as detected by immunogold reaction. Neuron 11:771-787. CrossRef Medline

Benardo LS, Prince DA (1982) Cholinergic excitation of mammalian hippocampal pyramidal cells. Brain Res 249:315-331. CrossRef Medline

Benke TA, Lüthi A, Isaac JT, Collingridge GL (1998) Modulation of AMPA receptor unitary conductance by synaptic activity. Nature 393:793-797. CrossRef Medline

Blasco-Ibáñez JM, Freund TF (1995) Synaptic input of horizontal interneurons in stratum oriens of the hippocampal CA1 subfield: structural basis of feed-back activation. Eur J Neurosci 7:2170-2180. CrossRef Medline

Bliss TV, Lomo T (1973) Long-lasting potentiation of synaptic transmission in the dentate area of the anaesthetized rabbit following stimulation of the perforant path. J Physiol 232:331-356. CrossRef Medline

Bredt DS, Nicoll RA (2003) AMPA receptor trafficking at excitatory synapses. Neuron 40:361-379. CrossRef Medline

Buchanan KA, Petrovic MM, Chamberlain SE, Marrion NV, Mellor JR (2010) Facilitation of long-term potentiation by muscarinic M1 receptors is mediated by inhibition of SK channels. Neuron 68:948-963. CrossRef Medline

Campanac E, Gasselin C, Baude A, Rama S, Ankri N, Debanne D (2013) Enhanced intrinsic excitability in basket cells maintains excitatoryinhibitory balance in hippocampal circuits. Neuron 77:712-722. CrossRef Medline

Chamberland S, Salesse C, Topolnik D, Topolnik L (2010) Synapse-specific inhibitory control of hippocampal feedback inhibitory circuit. Front Cell Neurosci 4:130. CrossRef Medline

Choi SY, Chang J, Jiang B, Seol GH, Min SS, Han JS, Shin HS, Gallagher M, Kirkwood A (2005) Multiple receptors coupled to phospholipase C gate long-term depression in visual cortex. J Neurosci 25:11433-11443. CrossRef Medline

Cole AE, Nicoll RA (1983) Acetylcholine mediates a slow synaptic potential in hippocampal pyramidal cells. Science 221:1299-1301. CrossRef Medline

Cole AE, Nicoll RA (1984) Characterization of a slow cholinergic postsynaptic potential recorded in vitro from rat hippocampal pyramidal cells. J Physiol 352:173-188. CrossRef Medline

Crépel V, Aniksztejn L, Ben-Ari Y, Hammond C (1994) Glutamate metabotropic receptors increase a $\mathrm{Ca}(2+)$-activated nonspecific cationic current in CA1 hippocampal neurons. J Neurophysiol 72:1561-1569. Medline

Davis CN, Bradley SR, Schiffer HH, Friberg M, Koch K, Tolf BR, Bonhaus DW, Lameh J (2009) Differential regulation of muscarinic M1 receptors by orthosteric and allosteric ligands. BMC Pharmacol 9:14. CrossRef Medline

Debanne D, Gähwiler BH, Thompson SM (1999) Heterogeneity of synaptic plasticity at unitary CA3-CA1 and CA3-CA3 connections in rat hippocampal slice cultures. J Neurosci 19:10664-10671. Medline

Dickinson BA, Jo J, Seok H, Son GH, Whitcomb DJ, Davies CH, Sheng M, Collingridge GL, Cho K (2009) A novel mechanism of hippocampal LTD involving muscarinic receptor-triggered interactions between AMPARs, GRIP and liprin-alpha. Mol Brain 2:18. CrossRef Medline

Dutar P, Bassant MH, Senut MC, Lamour Y (1995) The septohippocampal pathway: structure and function of a central cholinergic system. Physiol Rev 75:393-427. Medline

Edwards DA, Kim J, Alger BE (2006) Multiple mechanisms of endocannabinoid response initiation in hippocampus. J Neurophysiol 95:67-75. CrossRef Medline

Ferraguti F, Cobden P, Pollard M, Cope D, Shigemoto R, Watanabe M, Somogyi P (2004) Immunolocalization of metabotropic glutamate receptor lalpha (mGluRlalpha) in distinct classes of interneuron in the CA1 region of the rat hippocampus. Hippocampus 14:193-215. CrossRef Medline

Fitzjohn SM, Kingston AE, Lodge D, Collingridge GL (1999) DHPGinduced LTD in area CAl of juvenile rat hippocampus; characterisation and sensitivity to novel mGlu receptor antagonists. Neuropharmacology 38:1577-1583. CrossRef Medline

Frotscher M, Léránth C (1985) Cholinergic innervation of the rat hippocampus as revealed by choline acetyltransferase immunocytochemistry: a combined light and electron microscopic study. J Comp Neurol 239:237-246. CrossRef Medline

Fukudome Y, Ohno-Shosaku T, Matsui M, Omori Y, Fukaya M, Tsubokawa H, Taketo MM, Watanabe M, Manabe T, Kano M (2004) Two distinct classes of muscarinic action on hippocampal inhibitory synapses: M2- mediated direct suppression and M1/M3-mediated indirect suppression through endocannabinoid signalling. Eur J Neurosci 19:2682-2692. CrossRef Medline

Gibson HE, Edwards JG, Page RS, Van Hook MJ, Kauer JA (2008) TRPV1 channels mediate long-term depression at synapses on hippocampal interneurons. Neuron 57:746-759. CrossRef Medline

Giessel AJ, Sabatini BL (2010) M1 muscarinic receptors boost synaptic potentials and calcium influx in dendritic spines by inhibiting postsynaptic SK channels. Neuron 68:936-947. CrossRef Medline

Graves AR, Moore SJ, Bloss EB, Mensh BD, Kath WL, Spruston N (2012) Hippocampal pyramidal neurons comprise two distinct cell types that are countermodulated by metabotropic receptors. Neuron 76:776-789. CrossRef Medline

Greene CC, Schwindt PC, Crill WE (1994) Properties and ionic mechanisms of a metabotropic glutamate receptor-mediated slow afterdepolarization in neocortical neurons. J Neurophysiol 72:693-704. Medline

Guérineau NC, Bossu JL, Gähwiler BH, Gerber U (1995) Activation of a nonselective cationic conductance by metabotropic glutamatergic and muscarinic agonists in CA3 pyramidal neurons of the rat hippocampus. J Neurosci 15:4395-4407. Medline

Gulyás AI, Miles R, Sík A, Tóth K, Tamamaki N, Freund TF (1993) Hippocampal pyramidal cells excite inhibitory neurons through a single release site. Nature 366:683-687. CrossRef Medline

Hainmüller T, Krieglstein K, Kulik A, Bartos M (2014) Joint CP-AMPA and group I mGlu receptor activation is required for synaptic plasticity in dentate gyrus fast-spiking interneurons. Proc Natl Acad Sci U S A 111: 13211-13216. CrossRef Medline

Hebb DO (1949) The organization of behavior. New York: Wiley.

Heynen AJ, Bear MF (2001) Long-term potentiation of thalamocortical transmission in the adult visual cortex in vivo. J Neurosci 21:9801-9813. Medline

Horn R, Marty A (1988) Muscarinic activation of ionic currents measured by a new whole-cell recording method. J Gen Physiol 92:145-159. CrossRef Medline

Howe AR, Surmeier DJ (1995) Muscarinic receptors modulate N-, P-, and L-type $\mathrm{Ca} 2+$ currents in rat striatal neurons through parallel pathways. J Neurosci 15:458-469. Medline

Ireland DR, Abraham WC (2002) Group I mGluRs increase excitability of hippocampal CA1 pyramidal neurons by a PLC-independent mechanism. J Neurophysiol 88:107-116. Medline

Isaac JT, Nicoll RA, Malenka RC (1995) Evidence for silent synapses: implications for the expression of LTP. Neuron 15:427-434. CrossRef Medline

Jay TM, Burette F, Laroche S (1995) NMDA receptor-dependent long-term potentiation in the hippocampal afferent fibre system to the prefrontal cortex in the rat. Eur J Neurosci 7:247-250. CrossRef Medline

Kamsler A, McHugh TJ, Gerber D, Huang SY, Tonegawa S (2010) Presynaptic $\mathrm{m} 1$ muscarinic receptors are necessary for mGluR long-term depression in the hippocampus. Proc Natl Acad Sci U S A 107:1618-1623. CrossRef Medline

Kawasaki H, Palmieri C, Avoli M (1999) Muscarinic receptor activation induces depolarizing plateau potentials in bursting neurons of the rat subiculum. J Neurophysiol 82:2590-2601. Medline

Kim J, Isokawa M, Ledent C, Alger BE (2002) Activation of muscarinic acetylcholine receptors enhances the release of endogenous cannabinoids in the hippocampus. J Neurosci 22:10182-10191. Medline

Kullmann DM (1994) Amplitude fluctuations of dual-component EPSCs in hippocampal pyramidal cells: implications for long-term potentiation. Neuron 12:1111-1120 CrossRef Medline

Kullmann DM, Lamsa KP (2007) Long-term synaptic plasticity in hippocampal interneurons. Nat Rev Neurosci 8:687-699. CrossRef Medline

Lamsa KP, Heeroma JH, Somogyi P, Rusakov DA, Kullmann DM (2007) Anti-Hebbian long-term potentiation in the hippocampal feedback inhibitory circuit. Science 315:1262-1266. CrossRef Medline

Lawrence JJ, Statland JM, Grinspan ZM, McBain CJ (2006a) Cell typespecific dependence of muscarinic signalling in mouse hippocampal stratum oriens interneurones. J Physiol 570:595-610. CrossRef Medline

Lawrence JJ, Grinspan ZM, Statland JM, McBain CJ (2006b) Muscarinic receptor activation tunes mouse stratum oriens interneurones to amplify spike reliability. J Physiol 571:555-562. CrossRef Medline

Leão RN, Mikulovic S, Leão KE, Munguba H, Gezelius H, Enjin A, Patra K, Eriksson A, Loew LM, Tort AB, Kullander K (2012) OLM interneurons 
differentially modulate CA3 and entorhinal inputs to hippocampal CA1 neurons. Nat Neurosci 15:1524-1530. CrossRef Medline

Le Duigou C, Kullmann DM (2011) Group I mGluR agonist-evoked longterm potentiation in hippocampal oriens interneurons. J Neurosci 31: 5777-5781. CrossRef Medline

Le Roux N, Cabezas C, Böhm UL, Poncer JC (2013) Input-specific learning rules at excitatory synapses onto hippocampal parvalbumin-expressing interneurons. J Physiol 591:1809-1822. CrossRef Medline

Levey AI, Edmunds SM, Koliatsos V, Wiley RG, Heilman CJ (1995) Expression of $\mathrm{ml-m} 4$ muscarinic acetylcholine receptor proteins in rat hippocampus and regulation by cholinergic innervation. J Neurosci 15: 4077-4092. Medline

Liao D, Hessler NA, Malinow R (1995) Activation of postsynaptically silent synapses during pairing-induced LTP in CA1 region of hippocampal slice. Nature 375:400-404. CrossRef Medline

Lin YW, Min MY, Chiu TH, Yang HW (2003) Enhancement of associative long-term potentiation by activation of beta-adrenergic receptors at CA1 synapses in rat hippocampal slices. J Neurosci 23:4173-4181. Medline

Losonczy A, Zhang L, Shigemoto R, Somogyi P, Nusser Z (2002) Cell type dependence and variability in the short-term plasticity of EPSCs in identified mouse hippocampal interneurones. J Physiol 542:193-210. CrossRef Medline

Madison DV, Lancaster B, Nicoll RA (1987) Voltage clamp analysis of cholinergic action in the hippocampus. J Neurosci 7:733-741. Medline

Malinow R, Malenka RC (2002) AMPA receptor trafficking and synaptic plasticity. Annu Rev Neurosci 25:103-126. CrossRef Medline

Mannaioni G, Marino MJ, Valenti O, Traynelis SF, Conn PJ (2001) Metabotropic glutamate receptors 1 and 5 differentially regulate CA1 pyramidal cell function. J Neurosci 21:5925-5934. Medline

McCutchen E, Scheiderer CL, Dobrunz LE, McMahon LL (2006) Coexistence of muscarinic long-term depression with electrically induced longterm potentiation and depression at CA3-CA1 synapses. J Neurophysiol 96:3114-3121. CrossRef Medline

McQuiston AR, Madison DV (1999) Muscarinic receptor activity induces an afterdepolarization in a subpopulation of hippocampal CAl interneurons. J Neurosci 19:5703-5710. Medline

Morishita W, Kirov SA, Alger BE (1998) Evidence for metabotropic glutamate receptor activation in the induction of depolarization-induced suppression of inhibition in hippocampal CA1. J Neurosci 18:4870-4882. Medline

Morris RG, Anderson E, Lynch GS, Baudry M (1986) Selective impairment of learning and blockade of long-term potentiation by an N-methyl-Daspartate receptor antagonist, AP5. Nature 319:774-776. CrossRef Medline

Nicholson E, Kullmann DM (2014) Long-term potentiation in hippocampal oriens interneurons: postsynaptic induction, presynaptic expression and evaluation of candidate retrograde factors. Philos Trans R Soc Lond B Biol Sci 369:20130133. Medline

Oren I, Nissen W, Kullmann DM, Somogyi P, Lamsa KP (2009) Role of ionotropic glutamate receptors in long-term potentiation in rat hippocampal CA1 oriens-lacunosum moleculare interneurons. J Neurosci 29:939-950. CrossRef Medline

Palmer MJ, Irving AJ, Seabrook GR, Jane DE, Collingridge GL (1997a) The group I mGlu receptor agonist DHPG induces a novel form of LTD in the CA1 region of the hippocampus. Neuropharmacology 36:1517-1532. CrossRef Medline

Park JY, Spruston N (2012) Synergistic actions of metabotropic acetylcholine and glutamate receptors on the excitability of hippocampal CA1 pyramidal neurons. J Neurosci 32:6081-6091. CrossRef Medline

Pavlidis P, Montgomery J, Madison DV (2000) Presynaptic protein kinase activity supports long-term potentiation at synapses between individual hippocampal neurons. J Neurosci 20:4497-4505. Medline

Perez Y, Morin F, Lacaille JC (2001) A hebbian form of long-term potentiation dependent on mGluRla in hippocampal inhibitory interneurons. Proc Natl Acad Sci U S A 98:9401-9406. CrossRef Medline
Perkins KL (2006) Cell-attached voltage-clamp and current-clamp recording and stimulation techniques in brain slices. J Neurosci Methods 154: 1-18. CrossRef Medline

Rouse ST, Marino MJ, Potter LT, Conn PJ, Levey AI (1999) Muscarinic receptor subtypes involved in hippocampal circuits. Life Sci 64:501-509. CrossRef Medline

Scheiderer CL, Smith CC, McCutchen E, McCoy PA, Thacker EE, Kolasa K, Dobrunz LE, McMahon LL (2008) Coactivation of M(1) muscarinic and alphal adrenergic receptors stimulates extracellular signal-regulated protein kinase and induces long-term depression at CA3-CA1 synapses in rat hippocampus. J Neurosci 28:5350-5358. CrossRef Medline

Shigemoto R, Kinoshita A, Wada E, Nomura S, Ohishi H, Takada M, Flor PJ, Neki A, Abe T, Nakanishi S, Mizuno N (1997) Differential presynaptic localization of metabotropic glutamate receptor subtypes in the rat hippocampus. J Neurosci 17:7503-7522. Medline

Shinoe T, Matsui M, Taketo MM, Manabe T (2005) Modulation of synaptic plasticity by physiological activation of M1 muscarinic acetylcholine receptors in the mouse hippocampus. J Neurosci 25:11194-11200. CrossRef Medline

Szabo A, Somogyi J, Cauli B, Lambolez B, Somogyi P, Lamsa KP (2012) Calcium-permeable AMPA receptors provide a common mechanism for LTP in glutamatergic synapses of distinct hippocampal interneuron types. J Neurosci 32:6511-6516. CrossRef Medline

Thomas MJ, Moody TD, Makhinson M, O’Dell TJ (1996) Activitydependent $\beta$-adrenergic modulation of low frequency stimulation induced LTP in the hippocampal CA1 region. Neuron 17:475-482. CrossRef Medline

Topolnik L, Azzi M, Morin F, Kougioumoutzakis A, Lacaille JC (2006) mGluR1/5 subtype-specific calcium signalling and induction of longterm potentiation in rat hippocampal oriens/alveus interneurones. J Physiol 575:115-131. CrossRef Medline

Tyan L, Chamberland S, Magnin E, Camiré O, Francavilla R, David LS, Deisseroth K, Topolnik L (2014) Dendritic inhibition provided by interneuron-specific cells controls the firing rate and timing of the hippocampal feedback inhibitory circuitry. J Neurosci 34:4534-4547. CrossRef Medline

van Hooft JA, Giuffrida R, Blatow M, Monyer H (2000) Differential expression of group I metabotropic glutamate receptors in functionally distinct hippocampal interneurons. J Neurosci 20:3544-3551. Medline

Volk LJ, Pfeiffer BE, Gibson JR, Huber KM (2007) Multiple Gq-coupled receptors converge on a common protein synthesis-dependent long-term depression that is affected in fragile $\mathrm{X}$ syndrome mental retardation. J Neurosci 27:11624-11634. CrossRef Medline

Watts AO, van Lipzig MMH, Jaeger WC, Seeber RM, van Zwam M, Vinet J, van der Lee MMC, Siderius M, Zaman GJR, Boddeke HW, Smit MJ, Pfleger KD, Leurs R, Vischer HF (2013) Identification and profiling of CXCR3-CXCR4 chemokine receptor heteromer complexes. Br J Pharmacol 168:1662-1674. CrossRef Medline

Widmer H, Ferrigan L, Davies CH, Cobb SR (2006) Evoked slow muscarinic acetylcholinergic synaptic potentials in rat hippocampal interneurons. Hippocampus 16:617-628. CrossRef Medline

Wilson RI, Nicoll RA (2001) Endogenous cannabinoids mediate retrograde signalling at hippocampal synapses. Nature 410:588-592. CrossRef Medline

Yamasaki M, Matsui M, Watanabe M (2010) Preferential localization of muscarinic M1 receptor on dendritic shaft and spine of cortical pyramidal cells and its anatomical evidence for volume transmission. J Neurosci 30:4408-4418. CrossRef Medline

Zilberter M, Holmgren C, Shemer I, Silberberg G, Grillner S, Harkany T, Zilberter Y (2009) Input specificity and dependence of spike timingdependent plasticity on preceding postsynaptic activity at unitary connections between neocortical layer $2 / 3$ pyramidal cells. Cereb Cortex 19: 2308-2320. CrossRef Medline 